\title{
CONSTRUCTION OF RESEARCH ARTICLES IN THE LEADING INTERDISCIPLINARY ACCOUNTING JOURNALS
}

Charl de Villiers (University of Waikato Waikato New Zealand and University of Pretoria, Pretoria, South Africa) and

John Dumay (University of Sydney Business School, Sydney Australia

Corresponding author: John Dumay

john.dumay@sydney.edu.au

\begin{abstract}
$\underline{\text { Abstract }}$
Purpose: To examine the construction of articles published in three highly ranked interdisciplinary accounting journals.

Design/methodology/approach: We base our analysis on articles published during 2010 in Accounting, Auditing and Accountability Journal (AAAJ), Accounting, Organizations and Society (AOS) and Critical Perspectives on Accounting (CPA). In doing so, we develop a framework and examine characteristics of the published articles, including the prose. Findings: Based on the construction of accounting academic articles in the highly ranked interdisciplinary journals, we introduce a simplified concept of the five distinct major parts of an article. We also make some taken-for-granted aspects of article construction explicit and we conclude that alternatives, if used effectively, can add to the quality of an article. Finally, we conclude with a discussion of, and a reflection on, how the taken-for-granted rules of academic publishing can be challenged.
\end{abstract}

Research limitations/implications: This article is limited by the authors' own analysis and interpretations of AAAJ, AOS and CPA articles published during 2010.

Originality/value: As far as can be ascertained, we are the first to examine the construction of research articles published in high ranking interdisciplinary accounting journals. The paper can assist emerging scholars in the process of planning and writing their own articles. For seasoned researchers, our insights may serve to reaffirm or help further develop their approach. The paper also contributes to the ongoing debate around the pressure to publish, the measurement of publications, and the difficulties of getting published.

Key words: Academic publishing; writing; research; article attributes

Acknowledgements:

We would like to thank the many people who have given us feedback during the development of this paper.

Foremost we would like to thank James Guthrie for his support and insightful critique on several versions of this paper. Also, thanks to Lee Parker for his support and encouragement during the review process along with the insights from our two anonymous reviewers who have contributed to improving the quality of the paper in among other ways by suggesting additional avenues of investigation. Thanks also to Helen Sword (University of Auckland) and Imad Moosa (RMIT University) for their comments on early drafts of the paper.

Also thanks to the comments, observations and encouragement from the participants of numerous workshops and seminars where we have been invited to present our work, even though it was unpublished and still in development. The list includes, The University of Sydney Business School, University of Technology Sydney, Polytechnic University of the Marche (Ancona, Italy), Roma Tre University (Rome), Stockholm University Business School and the Kobe Graduate School of Business Administration (Japan). Another thanks to the encouragement and feedback from participants of the 2012 Accounting and Finance Association of Australia \& New Zealand (AFAANZ) Conference. Also special thanks to Fiona Crawford of the Editorial Collective for her sterling editorial advice. 


\section{Introduction}

Accounting academics increasingly lament the 'publish or perish' mentality that mandates publishing in highly ranked journals (Gendron, 2008; Hopwood, 2008; Harzing, 2010). The top tier journals get at least ten times as many submissions as they are able to publish, ensuring low acceptance rates (Guthrie and Parker, 2012). In this paper, we examine research articles published in three high ranking interdisciplinary accounting journals. Accounting, Auditing and Accountability Journal (AAAJ), Accounting, Organizations and Society (AOS) and Critical Perspectives on Accounting (CPA) were selected because they are distinctive in terms of being highly regarded qualitative journals in the sociological, critical and interpretative tradition. Each of these three journals also publishes contemporary and historical accounting articles. We will refer to these journals as interdisciplinary accounting journals throughout this paper. We examine several attributes of published articles in these journals, including the writing style used.

The paper is intended to be beneficial for emerging scholars, because it comments on and shows how different attributes of research articles have been combined, potentially assisting them in planning and writing their own articles. We do not suggest a specific article formula, but rather present evidence to show how different article attributes have been successfully combined in different ways in our sample of analysed articles. Our insights may also reaffirm or develop the approaches of more experienced authors who have published in these journals before. Our paper also contributes to the ongoing debate around publication pressure, publication measurement, and the difficulties experienced in having papers accepted for publication. Editors, associate editors, editorial board members, and reviewers of other interdisciplinary and specialist accounting journals may also gain valuable additional insights into the construction of academic articles. Additionally, our analysis may enlighten and change attitudes and behaviours of various participants in the publication process.

In the next section we review the contemporary environment in accounting academia and discuss the growing pressure to publish in highly ranked academic journals. This is followed by a section on what we can learn about academic article patterns; a section on the research method used; a results section, including an analysis and discussion of the patterns discernible from the research articles we examine; and finally a conclusion.

\section{Background: The pressure to publish in high ranking journals}

The pressure for accounting academics to publish in high ranking academic journals appears to continue to grow (Ballas and Theoharakis, 2003, p. 619; Guthrie et al., 2004; Gendron, 2008; Hopwood, 2008; Harzing, 2010). Indeed, both Harzing (2010) and Englebrecht et al. (2008) refer to the 'publish or perish' phenomenon and comment on the resulting behavioural adjustments academics are forced to make. Increasingly, funding for accounting disciplines and staff members is predicated on the number and perceived quality of academic journal publications. ${ }^{1}$

In addition to monetary rewards, academics use highly ranked publications to apply for and justify promotion, tenure, research grants and travel funding ${ }^{2}$ (Bédard and Gendron, 2003). Research output is also used in redundancy decisions. For example, in 2011 the University of Sydney 
announced a redundancy plan whereby research output was the main selection criteria for academic

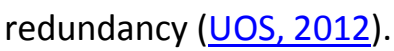

Two major questions for accounting academics under pressure to improve or retain their positions are "What is a highly ranked journal?" and "What counts as quality research?" (Northcott and Linacre, 2010, p. 39). The use of journal rankings has become very important in assessing academics, sometimes leading to unintended and undesirable behavioural consequences among researchers, for example, steering clear of 'risky' research projects and thereby staunching innovation (Hopwood, 2008). Indeed, research quality assessment can be controversial and can be a source of personal stress, impacting on job satisfaction, research 'efficiency', and choice of research direction. The journal ranking questions we pose above are not easily answered, as the merits of publishing in specific journals differ depending on a researcher's geographic region, research orientation, and the ranking system of individual universities (Ballas and Theoharakis, 2003). Table 1 shows the different rankings for $A A A J, A O S$ and $C P A$ in relation to other highly ranked journals.

[Insert Table 1 here]

There are many differences between journal quality rankings. For example, $A A A J$ is not included in the Thompson ISI rankings (not ranked in Table 1 due to copyright restrictions). Therefore academics whose promotion and tenure prospects are predicated on Thompson ISI ranked journals are likely to ignore $A A A J$ and favour other journals. Australian based academics may see $A A A J$ as a target journal, because $A A A J$ is included in the Australian ERA rankings, but a North American based academic is likely to prefer the journals backed by the American Accounting Association (

Two different methods of assessing research quality, namely a journal focus or an article focus, can yield totally different outcomes. Both journal quality and article quality can be based on the number of citations or on a ranking by academic experts. For Australian academics (and probably others too), citations is becoming a more important issue, with the Australian Research Council (ARC) moving away from relying on journal rankings. This could entail placing greater reliance on the citations of published articles, similar to the UK's proposed Research Excellence Framework (REF) (Rosenstreich and Wooliscroft, 2009). The current ARC (2011) guidelines place more emphasis on the number and quality of citations of a research article rather than a journal ranking predetermined by a panel of academic experts (see Moosa, 2011, pp. 809-10).

Another important issue is the research orientation of the author and of the author's geographical region and university. The top ranking journals in North America are skewed toward publishing positivist research, suggesting that North Americans are more likely to publish in positivist journals, than a more qualitative journal (Bédard and Gendron, 2003, p. 192). Indeed, according to Glover et al. (2006, p. 213), US accounting professors eschew publishing in AOS prior to promotion to full professor status. A different research culture is reflected in the journal rankings used in Australia and the UK, where more journals publishing qualitative and interdisciplinary research are included in the highly ranked categories (Guthrie and Parker, 2006). In short, North American academics concentrate more on positivist studies than their Australian and UK counterparts and these differing orientations lead to different views on journal quality.

The pressure to publish appears to be widespread in the accounting academic community. Therefore, academics are highly motivated to aim for a top journal publication. 


\section{Structure and pattern in academic accounting articles}

According to Pfeffer (2007, p. 1341), "This pressure to publish in the [highly] ranked journals, which tend to be U.S.- centric, along with the recruiting of faculty in a global labor market, has contributed to the production of some degree of theoretical isomorphism". Hopwood (2008) bemoans the tendencies towards standardisation that result from these pressures and we would argue that there is less theoretical isomorphism among articles published in the interdisciplinary journals than in the North American journals. However, we are interested in assessing whether the structure as opposed to the underlying theory of published articles in the high ranking interdisciplinary journals display elements of similarity, an "academic accounting article pattern" of sorts that can be followed. These patterns are not always fully understood by authors and researchers (see Carmona, 2011). So both the elements of an article and the way the elements are combined needs careful consideration. In this article, we explore these issues by analysing the attributes of articles published in three highly ranked interdisciplinary accounting journals, where the differing underlying assumptions of the articles published makes it especially difficult to find common ground.

Finding the common ground between journals is especially difficult because each journal has its own objectives and style preferences. Therefore, to assist authors, most journals have specific guides on the scope of the journal and the style of article expected. We reproduce below excerpts from the websites of each of the three journals ${ }^{3}$ to show their differing emphases:

The Accounting, Auditing \& Accountability Journal is dedicated to the advancement of accounting knowledge and provides a forum for the publication of high quality manuscripts concerning the interaction between accounting/auditing and their socio-economic and political environments. It therefore encourages critical analysis of policy and practice in these areas. Analysis could explore policy alternatives and provide new perspectives for the accounting discipline.

Accounting, Organizations \& Society is a major international journal concerned with all aspects of the relationship between accounting and human behaviour, organizational structures and processes, and the changing social and political environment of the enterprise.

Critical Perspectives on Accounting aims to provide a forum for the growing number of accounting researchers and practitioners who realize that conventional theory and practice is ill-suited to the challenges of the modern environment, and that accounting practices and corporate behavior are inextricably connected with many allocative, distributive, social, and ecological problems of our era.

Journals usually have specific style requirements. Therefore, submissions should adhere to the style guidelines as published on journal websites or risk an early rejection. For example, CPA not only publishes an extensive webpage for prospective authors, ${ }^{4}$ it also has a PDF publication called the Author Information Pack as a resource available from a link on the same webpage. Notably, the CPA guidelines even contain specifications for the article structure, offering a 'standardised structure' for publishable articles. AOS has a similar guideline, but does not offer a standard format for articles. AOS does offer advice on attributes such as 'Abstracts', 'Footnotes', and 'Referencing'.

But following specific journal guidelines does not guarantee success for two key reasons. First, because of increasing submissions to top tier journals, the competition for a limited number of 
places is fierce, especially as these journals continue to serve a growing community of global academics (Guthrie and Parker, 2012). As Primack (2009) outlines, articles may be publishable, but if there is no room for them in the journal, the article may still be desk rejected and an alternative journal for publication of the article sought.

Second, the paper may be defective in some area, leading to reviewers recommending rejection. Reviewers reject for similar reasons as editors, but the process is imperfect, so editors occasionally send out a paper for review that should have been desk rejected. In a study based on accounting education paper submissions, Stout et al. (2006, p. 81) outline why papers are rejected by reviewers;

The reasons for rejection are generally manifested early in the life of the project. Primary reasons for rejection are (1) a poorly motivated study, (2) a poorly designed study, and/or (3) an insignificant contribution to the accounting education literature. Poor writing is a common secondary reason for rejecting accounting education research manuscripts. The most common reason a manuscript was rejected after resubmission was the failure of the author to adequately address concerns expressed by reviewers and the editor during previous review rounds.

Authors will want to avoid these common reasons for rejection. However, avoiding the reasons for rejection does not guarantee acceptance. Examining the attributes of published articles allows us to identify how these attributes are utilised in practice. For example, academic articles are often accused of being too long and boring (Wolff, 2007) and have been getting longer (Ellison, 2002). Article length impacts the number of articles a journal can publish, because publishers limit the number of journal pages in a specific year (volume). Longer articles have also been blamed in part for the increase in the amount of time taken from submission to publication, because longer articles take longer to review and revise (Ellison, 2002). Therefore, examining published articles for their length relative to journal guidelines would be interesting. We could not find any prior research that examined this characteristic of research articles. Additionally, the academic literature has concentrated on the reasons for rejecting rather than accepting papers (for example,Howard and Stout, 2006; Stout et al., 2006; Primack, 2009). Thus our research questions are: "How are the attributes utilised in the selected articles?" and "What can we learn from these attributes to inform or affirm our approach to writing papers destined for high ranking journals (such as AAAJ, AOS and (PA)?"

\section{Research method}

Our analysis focuses on articles in three top tier interdisciplinary accounting journals, AAAJ, AOS and CPA. All three are highly ranked accounting journals, as highlighted in Table 1 , and all three are commonly identified as interdisciplinary. Nevertheless, the journals have different aims as was evident from the excerpts above. Specifically, AOS emphasises "the relationship between accounting and human behaviour, organizational structures and processes, and the changing social and political environment of the enterprise", while $A A A J$ focus on "the interaction between accounting/auditing and their socio-economic and political environments". With "critical perspectives" in the journal's title, CPA is specifically positioned as a journal focused on critical scholarship in accounting. These similarities and differences make a comparison of the requirements of, and the articles published in, these journals of interest to a broad audience of research active accounting academics. 
We analysed all of the full research articles published in 2010 in the journals. We excluded poems (Baker, 2010a), editorials (Parker and Guthrie, 2010), and short commentaries (Laughlin, 2010). Our analysis focused on the characteristics of the selected articles. Our research framework was developed in several iterative stages as we first examined surface characteristics and then delved deeper. First, we had a PhD student analyse the articles based on the six generic sections of an article Abstract, Introduction, Method, Analysis, Discussion, and Conclusion (see Guthrie et al., 2004 p. 417): searching common attributes such as word count, number of tables, figures, and footnotes. At this stage many sections were classified as 'Other', because these sections were not labelled in ways that facilitated classification.

As a result one author further refined the analytical framework to capture more subtle detail to eliminate the 'Other' category. Both authors tested, reviewed and refined the framework further before allowing the PhD student to reclassify the articles and this was again audited by one author for consistency. We will now describe the final analytical framework used to analyse the articles and present the reasoning behind our choice of framework (see Table 2).

[Insert Table 2 here]

The first four attributes, namely 'Journal', 'Page numbers', 'Authors', and 'Article name' are obvious distinguishing characteristics. The fifth attribute, 'Article type' was required by $A A A J$, but not by $A O S$ or CPA. We also identified articles as qualitative or quantitative, with the latter defined as articles with numerical data and more in depth statistical analyses. Articles not meeting these criteria were classified as qualitative.

\section{Article structure}

The next area of analysis is article structure. Here we broke the articles into different sections based on their purpose; a challenging task as many sections had overlapping boundaries. For example, some articles had a section called 'Discussion and conclusions' (for example Agyemang, 2010; van Veen-Dirks, 2010) or 'Conclusions and discussion' (Mäkelä and Näsi, 2010) or 'Results and discussion' (Gibbins et al., 2010). Thus we needed to examine each section closely to decide how to classify it. As a result, we identified twelve different categories as shown in Table 2. For each of the categories we recorded the name, position (order) and the word count of each section, excluding references. In $A A A J$ we identified a specific 'Notes' category for endnotes, whereas AOS and CPA use footnotes at the bottom of each page. We also counted the number of each of the following: references, journal self-citations (i.e., citations of articles in the same journal), author self-citations, tables, figures, equations, plates and exhibits.

\section{Article style}

We then turned to the more elusive characteristics we refer to as attributes of style, because this is an area where both reviewers and editors can sometimes impose their personal beliefs about what an article should look like, that is, authors may be forced to adhere to a specific writing style. For example, we examined the use of the first or third person perspective. The perspective issue is interesting, because many take it for granted that academic writing should be impersonal and scientific and thus we should 'distance' ourselves from the reader by using a third person perspective (Brick, 2005, p. 1). Brick (2005, p. 2) advocates that academic writing should be 
"objective ... so it is impersonal" with limited use of the pronoun "I" (or its alternatives "we" and "our"). However, when there is a need to be authoritative the personal voice might be used with good effect, for example "In this article I describe..." Some journal editors have a distinct policy of ensuring articles are written in the third person. ${ }^{5}$

Issues of style also permeate through to the 'abstractness' of academic writing. This is especially important if academics hope to reach beyond an academic audience, because academic writing can be boring and does not capture the nuances of "plot" and "story" because articles are often written as a logically ordered sequence, instead of showing "enough of the narrative sequence to get an impression of what is going on, and to whet their [readers'] appetite for more" (Wolff, 2007). Wolff (2007) elaborates that this is because "professional academic style, then, is formed early on, and reinforced thereafter. It is rather hard to escape the conclusion that academic writing is boring because academics wouldn't have it any other way".

As a result academic authors tend to revert to the writing styles that they have been taught from the beginning of their academic days. Thus, many authors use abstract nouns, such as "organisation", rather than concrete nouns, such as "company", because they are taught that academic writing should be "analytical ... so it is abstract and focussed" rather than interactive and spontaneous (Brick, 2005, pp. 1-2). This, we argue, contributes to the accusation that academic writing is boring and abstract, as Sword (2009, p. 319) elaborates:

My student-colleagues are hungry to learn, but they display an extremely low tolerance for the kind of impersonal, impenetrable prose that has become the dominant written discourse of the social sciences. They want stories, examples, ideas, solutions - not long parenthetical references, convoluted flowcharts and truckloads of... jargon.

Reviewers (i.e., authors taking on a different role) also share the same complaint. Sword (2009, p. 319) elaborates further in her study about what we as academics like compared to what we produce:

According to a recent survey of colleagues across the disciplines, the most effective and engaging academic writers are those who express complex ideas clearly and succinctly; write with originality, imagination and creative flair; convey enthusiasm, commitment and a strong sense of self; tap into a wide range of intellectual interests; avoid excessive jargon; employ plenty of concrete examples and illustrations; demonstrate care for their readers; and know how to tell a good story. Yet an analysis of 100 peer-reviewed articles in six top-ranked higher education journals ... reveals no more than a handful of academic authors who exhibit any, much less all, of those characteristics.

\section{Measurement framework}

We needed a measure of academic writing that was objective, repeatable, comparable, and reliable for our own analyses of $A A A J, A O S$ and CPA articles. We chose Helen Sword's (2007, pp. 3-5) The Writer's Diet website where she developed the "Wasteline Test". Sword's (2007) test determines the relative "fitness" of academic writing based on five categories "commonly associated with stodgy sentences". ${ }^{6}$ Her test assesses academic prose as a diagnostic rather than a prescriptive tool. By analysing academic writing using the five categories of "weak verbs, abstract nouns, prepositions, adjectives/adverbs and 'waste words' (it, this, that, there)", an overall "fitness ranking" can be determined. To determine a numerical outcome we applied a score to each of Sword's "fitness 
rankings" of "Lean" (0), "Fit and trim" (1), "Needs toning" (2), "Flabby" (3) and "Heart attack territory" (4). We use this score to focus attention on the current structure of academic prose rather than as a tool to criticise writing.

Once we defined the analytical framework in Table 2, we identified some specific topic areas for discussion based on our first research question. We will next discuss our findings in line with the analysis framework outlined in Table 2.

\section{Results and discussion}

In this section, we outline descriptive statistics about the articles and, where applicable, how they compare to any stated objectives or publishing guidelines issued by the respective journals. We also discuss the results, the rhetoric of the guidelines, the taken-for-granted beliefs about practice, and the differences between the journals.

\section{To co-author or not to co-author?}

For some time now many accounting research articles have had more than one author (Beattie and Goodacre, 2004, p. 7), a growing trend since the advent of publishing accounting research in the 1920s (Heck and Bremser, 1986, p. 736; Heck and Jensen, 2007, pp. 112-4). For example, the incidence of co-authorship in the British Accounting Review from 1997 to 2006 was 59\% overall, but increased over the period (Beattie and Emmanuel, 2008, p. 198). Co-authoring is believed to increase the quality of an article (Beattie and Emmanuel, 2008), leveraging the different knowledge and skills different authors bring to the research project (Beyer et al., 2010), as well as sharing the writing and research workload. For example, one author's familiarity with a specific journal, based on previous review and publication experience, can complement another author's statistical and analytical skills. Mentoring, such as a prominent professor working with a PhD student to help get the student's research published, is another common reason for co-authorship. Additionally, Englebrecht et al. (2008, p. 178) found the incidence of co-authorship in premier accounting journals to have significantly increased over the period from 1979 to 2004, and that trends of co-authorship are not statistically different between US and non-US academic researchers. Englebrecht et al. $(2008$, p. 172) also argue that this may be due to "the 'publish or perish' phenomena for academic researchers is a more significant factor of increased co-authorship rates than other universal factors". Therefore, we would expect the majority of AAAJ, AOS and CPA articles to be co-authored.

Table 3 shows the authorship of research articles published in AAAJ, AOS and CPA during 2010. The majority of $A A A J(74 \%), A O S(67 \%)$ and CPA (63\%) articles were co-authored. Additionally Table 3 shows that the majority of articles published had at least one co-author who had published in the particular journal before, AAAJ (59\%), AOS (77\%) and CPA (67\%). Predominantly, previously published authors pair with unpublished authors, especially $A A A J$, as the number of new authors exceeds the number of authors who have published previously, AAAJ (74\%), AOS (53\%) and CPA (53\%). Therefore, a reasonable strategy seems to be to choose co-authors based on their prior publication success or to choose a well published author as a PhD supervisor with an eye on eventual joint publication and collaboration.

[Insert Table 3 here] 
Overall, our results suggest that $A A A J$ is more open to "newcomers" or at least to emerging scholars who have not published in the journal before than the other two journals. This may be related to the community development initiatives of the editors of $A A A J$ or the effects of its policy of publishing a sizable number of special issues and, thereby, stimulating the interest of scholars with an array of different interests. Nevertheless, $A A A J$ appears to be more willing to introduce new authors, and thereby assist in developing future scholars, than the other two journals based on these results.

\section{Construction of an article}

As mentioned before, a poorly structured paper can be grounds for a major revision or a rejection. Thus, an analysis of the construction of published articles offers insights into the attributes of the articles and how these have been utilised by different authors. We analysed the AAAJ, AOS and CPA articles for their structure by classifying each part according to our framework and counting the number of words in each section. According to Guthrie et al. (2004 pp. 416-8) research articles generally contain five major sections: introduction, methodology, findings, analysis and conclusion. As a result of our analysis we argue for a slightly expanded general framework, as outlined in Table 4.

\section{[Insert Table 4 here]}

Not all articles followed this structure exactly. As Sword (2007) outlines, if everyone used the same writing style, academic writing would be even more boring. The articles we analysed show that articles with both simple and complicated structures are published. An example of a simple, easy to follow structure, is the AOS article by Toms (2010a), who uses only five of the classified sections: Abstract; Introduction; Profitability: a theoretical re-examination (Theory); ROCE calculations: empirical evidence (Results); and Conclusions. Toms (2010c) is equally frugal in his AAAJ article, again only using a minimum number of sections, namely: Abstract; Introduction; Strategy, value theory and accounting; Conceptual framework; Discussion; and Conclusions. An even simpler structure is used in the CPA article by James (2010a), who has only four sections: Abstract; Introduction and theoretical framework; Lyrics study; and Conclusions. CPA also evidences only five sections in nine other articles (Asenova and Beck, 2010; Ball and Craig, 2010; Guidi et al., 2010; Hanlon, 2010; Josiah et al., 2010; McKinlay and Pezet, 2010; Noël et al., 2010; Toms, 2010b; Young and Williams, 2010)

But journals also accept complex articles with numerous sections and headings. For example, the three AOS articles respectively by Carmona et al. (2010), Frow et al. (2010) and Kuasirikun and Constable (2010) all have ten distinct sections. Similarly, AAAJ articles by Merino et al. (2010), Lapsley and Giordano (2010) and Samkin and Schneider (2010) have nine sections each. While CPA had the most articles with fewer sections it also holds the distinction of having the most articles with numerous sections (equal with $A O S$ ), with three articles having ten sections (Arnaboldi and Azzone, 2010; Haynes, 2010; Mete et al., 2010) and four articles having nine (Christopher, 2010; Killian, 2010; Lehman, 2010; Roslender and Hart, 2010).

Along with articles having many sections, some articles lacked seemingly crucial sections, such as a formal 'Conclusion'; in AOS see Cianci and Kaplan (2010); O'Donnell and Prather-Kinsey (2010); and Schultz Jr et al. (2010) and in CPA see Cooper et al. (2010); Fogarty and Jonas (2010); Pipan and Czarniawska (2010); Sikka and Willmott (2010); and Spence et al. (2010). However, the final sections of these articles include some of the elements of a typical conclusion section, for example, Cianci 
and Kaplan (2010) devote their final paragraph to outlining their research limitations and their previous two paragraphs to summarizing their findings. We found it to be fairly common to see one or more of the major sections of an article missing and/or not specifically identified.

\section{Article length}

As stated earlier, a common complaint about academic articles is that they are long and boring. While AOS and CPA do not publicly reveal a word count guideline, the editors of $A A A J$, at the time under review, advised on their website that "As a guide, articles should be between 6,000 and 12,000 words in length". ${ }^{7}$ We expected, therefore, most of the $A A A J$ articles to fit this range. We recorded the word count for each section of each article (excluding references) in an attempt to define what is commonly acceptable. We did this by copying the text from a PDF version of the article into a Microsoft Word file and relied on the word count feature. For this task, we combined like sections: for example, the Christensen and Skærbæk (2010) article has four appendices, therefore we combined the word count for these sections. Similarly, we identified five different 'Discussion' sections in the Carmona et al. (2010) article, so we combined these under a single word count. From these word counts we calculated a 'Total Word Count (TWC)', including all sections except 'Acknowledgements' and 'References'.

As shown in Table 5, our analysis found that the majority of articles published in 2010 are longer than the $A A A J$ guideline with a mean word count of 11,366 words. In fact, AAAJ, AOS and CPA all publish articles in excess of the median 9,000 word expectation of AAAJ. AAAJ consistently exceeds its mean guideline with a mean word count of 10,485 , compared with $A O S$, which publishes significantly longer articles with a mean word count of 14,363. The Gendron and Spira (2010) and Mennicken (2010) AOS articles provide two notable examples of articles far in excess of 20,000 words. However, CPA publishes on average shorter articles with a mean word count of 9,617 and did not publish any articles in excess of 20,000 words.

\section{[Insert Table 5 here]}

As all the journals publish fairly long articles this may disadvantage them against similar quality journals that publish shorter articles that compete for readers, and eventually recognition through citations. Long articles may force readers to use shortcuts, for example, to read only the abstract, introduction, and/or conclusion sections. Such shortcuts may influence their ability to accurately assess the reliability and validity of research on which they rely.

\section{The introduction}

As we outlined in our research framework we have classified the 'Abstract', 'Introduction' and 'Literature review / hypotheses' as part of the general 'Introduction' of an article. As part of our analysis we examined the word count of these sections and as expected, the AOS articles had a higher word count than $A A A J$ articles for the 'Introduction', 'Literature review / Hypotheses' and 'Context' sections. The average AAAJ 'Abstract' was longer (260 words) than in AOS and CPA (171 words each). We will discuss the differences between the AAAJ, AOS and CPA 'Abstract' next followed by a more detailed analysis and discussion of the 'Introduction', 'Literature review / Hypotheses' and 'Context' sections. 


\section{The 'Abstract'}

The difference between the AAAJ, AOS and CPA 'Abstract' word counts may be due to AAAJ's requirement that all articles have a 'Structured Abstract', as opposed to AOS and CPA, which allows an unstructured paragraph. The AOS Author Guidelines" state "The abstract should state briefly the purpose of the research, the principal results and major conclusions", while CPA provides exactly the same advice (both Elsevier publications). A good example of a simply written AOS abstract is offered by O'Donnell and Prather-Kinsey (2010, p. 558).

This study examines whether auditors from different countries come to different conclusions when they perform analytical procedures to assess the risk of misstatement in accounts. During a laboratory experiment, auditors who worked for the same firm in the United Kingdom, France, and the United States performed analytical procedures on identical case materials. Although auditors from all three countries came to similar conclusions about the overall risk of misstatement, they attributed risk differently across the individual financial statement accounts they evaluated.

A similarly concise CPA 'Abstract' is offered by Rahaman (2010, p. 420).

This paper provides a review of the critical accounting literature on Africa highlighting the paucity of studies in this area and outlining the objective of this special issue of Critical Perspectives on Accounting. The paper also provides some directions for future critical accounting research focused on Africa, arguing that the continent presents significant research opportunities for the critical accounting community and therefore joins the chorus for more scholarship in this area.

By contrast, a 'Structured Abstract' for an Emerald journal, ${ }^{9}$ such as $A A A J$, needs to provide separate information under the following headings:

- Purpose (mandatory)

- Design/methodology/approach (mandatory)

- Findings (mandatory)

- Research limitations/implications (if applicable)

- Practical implications (if applicable)

- Social implications (if applicable)

- Originality/value (mandatory).

The merits of structured abstracts versus 'unstructured abstracts' is the subject of some debate among academics and within the ranks of Emerald journal editors. The benefits of structured abstracts are supposedly (Mosteller et al., (2004, p. 29):

The structured abstract is a viable and useful innovation to help practitioners and policymakers systematically access, assess, and communicate [...] studies and research findings ... the structured abstract provides a more robust vehicle for disseminating research through traditional routes as well as through new channels made possible by emerging technologies.

\section{The 'Introduction'}

The 'Introduction' is an important part of a research article. The author can (and must) use the 'Introduction' to explain and 'sell' the article. The 'Introduction' has to explain what was done, how it was done, and why this is important and of interest to the audience targeted by the journal. This includes the contribution the article makes to the research field. In a sense, the 'Introduction' summarises the whole article and explains how the question, the prior research, and the method fits 
together to provide insight. There is no standard approach to achieve this and the state of the research field may dictate the best approach at the time. However, the 'Introduction' paragraph needs to be well written in order to convey its message properly and thus we have targeted the 'Introduction' as the basis for our analysis of writing structure. As we outlined in the research framework we have utilised Sword's (2007, pp. 3-5) "Wasteline Test" to examine the structure of the 'Introduction' of the 2010 AAAJ, AOS and CPA articles.

While Sword (2007) does not provide a numerical rating we have adapted her ranking system to include a score as outlined in the research framework. Thus, each of the five categories of the test is scored on a scale from 4 - "Heart attack", 3 - "Flabby", 2 - "Needs toning", 1 - "Fit \& trim", and 0"Lean" giving a total score out of 20. We used the online test version ensuring objectivity and comparability. Also, to ensure we only analysed the authors' own words we excluded direct quotations and references. Figure 1 displays the mean scores for each category.

\section{[Insert Figure 1 here]}

Our findings do not show any significant difference between AAA, AOS or CPA writing styles, but when we analysed each style component, we observe how most authors do get high scores under the 'Abstract nouns' category. For example, in academic accounting articles, many authors appear to use nominalisations - that is, abstract nouns that have been formed from verbs and adjectives such as 'organisation' instead of referring directly to the type of organisation they are writing about such as a 'company' or 'firm'. Thus, it is not surprising to find a high percentage of abstract noun use.

A high percentage of abstract nouns can contribute to longer sentences and longer articles, because instead of using the directly appropriate noun from the outset, the use of an abstract noun often necessitates clarification later on (Sword, 2009). Based on the corresponding author's writing experience the number of words can be reduced in most samples of academic writing by $10-20 \%$ by editing the sample until it attains a 0 or 1 score on the test, while at the same time ensuring the other scores remain the same or improve. On this basis, a less abstract style of writing could reduce $A A A J, A O S$ and CPA article lengths anywhere between 1000 to 5000 words. Academic articles can be shorter and appear less boring with a reduction in the use of abstract nouns, dispensing with these criticisms (Sword, 2009). Of course, eliminating abstract nouns does not guarantee smaller word counts. "Waistline" scores can also be improved while maintaining or increasing word counts by providing concrete examples rather than abstract arguments or by converting abstract nouns back into verbs or adjectives. The lowest overall scores with an 'Abstract noun' rating of 1 ('Fit and trim') or less were the Kornberger et al. (2010) in AOS; ,Toms (2010c) in AAAJ; and Bettner et al. (2010) and Killian (2010) in CPA. These articles demonstrate how to write in a more engaging, non-abstract style.

Because 'abstractness' can influence word count, we investigated whether there was a correlation between the two in our sample of articles. However, a correlation analysis of writing style using the total Writer's Diet scores the length of articles does not show any relationship between the two $\left(r^{2}\right.$ of 0.02), suggesting that most academics write the way they do because they have been taught that way and not to reduce word counts. Similarly, as shown in Figure 1 AOS papers have a higher "Adjectives and adverbs" score suggesting that a possible reason for the greater length of AOS papers is that $A O S$ authors use a more descriptive and thus wordier style of writing. Again, a 
correlation analysis between paper length and the "Adjectives and adverbs" score did not suggest this to be the case.

Before moving on, we would like to acknowledge that an abstract style can be very effectively used in qualitative research articles, but we suggest that authors at least consider writing in a more nonabstract style.

\section{First versus third person?}

As we discussed earlier, academics are often taught to write impersonally, from a third person perspective, to distance ourselves from the research and to enhance the appearance of scientific objectivity. However, writing in the first person can be more direct and more effective in highlighting an author's own point of view. The use of the first person can actually strengthen arguments and make them more persuasive (Brick, 2005, pp. 8-11). Writing in the first person is a personal choice of style and is widely accepted in accounting journals. There are articles written in both the first and third person in $A A A J, A O S$ and CPA. While $A A A J$ does publish some articles in the first person the majority $(77 \%)$ are still written in the third person. AOS published proportionately more articles in the first person than $A A A J$, although most articles are in the third person (56\%) while CPA was an even split (50\%).

We suspected that the first person perspective is conducive to a more engaging writing style. So we were curious to discover whether writing in the first person could enhance the abstract style of academic writing we had previously identified. Our analysis showed this is not the case in our sampled articles. In fact our sample shows articles written in the first person can be more abstract than those written in the third person. Of course, we are limited to the articles published and cannot compare the academic writing of a single author using the first and third person perspective. So causation may go the other way, namely the authors in our sample who chose the first person may, on average, be slightly less skilled at engaging writing than the authors choosing the third person and this may have influenced their choice of first person writing. Another reason could be that the articles analysed are all written in a very abstract manner that leaves little room for improvement, even when the first person is used. The similarity between the other measures of the "Wasteline test" provides evidence in support of this argument.

\section{What is the road map paragraph and do I need it?}

The road map paragraph is a common feature of most academic accounting articles. The road map paragraph has its origins in the preparation of legal briefs. Levinson (2009) explains a road map paragraph as:

... one that sets out the points that will be discussed in more depth in the sections or sub-sections to follow. It is vital that an introduction contain such a paragraph because legal readers are busy individuals who like to see the conclusion and supporting points up-front. The roadmap paragraph is also important because it provides an overview of what will follow. The roadmap helps the reader to place the sections in context as they read. It also permits those who read no further than the introduction to get an understanding of the entirety of the argument.

Road map paragraphs are mostly used in our sample of $A A A J, A O S$ and CPA articles. In AAAJ five articles do not feature a road map paragraph, with the figure for AOS and CPA being eight and 16 respectively. The higher number in the case of CPA may be due to the fact that authors in that 
journal take a more critical stance on all matters, including questioning article conventions, such as the need for a road map paragraph. Alternatively, it could be due to some form of editorial input.

Many of the road map paragraphs we examined were nothing more than a quick outline of what came next, thus ignoring the purpose according to Levinson (2009). In contrast there were a few well written road map paragraphs that achieved the purpose of explaining the article's argument. The road map paragraph by Baker (2010b, p. 849) is a good example:

The structure of this paper is as follows. The first section reviews the development of managerial capture in the SEA literature. The second section compares the evidence of managerial capture with models of participative democracy as inspired by Habermas. The third section raises some generic questions as to the relevance and adequacy of the use of Habermas as an ideal model for understanding stakeholder engagement. The fourth section introduces Foucault's ideas of discipline in order to provide an alternative framing of managerial capture. This section suggests that capture itself can be seen as an effect of the more pervasive financial visibility, which shapes management subjectivities. The fifth section draws on empirical studies to explore and illustrate these disciplinary effects and the ways they condition management attitudes and beliefs in relation to the environmental and stakeholder engagement. The paper concludes by drawing out practical insights of this analysis of capture in relation to engagement and future research.

On the other hand, a good story keeps us in suspense and using a road map paragraph that tells us all the answers, may not keep us interested as Sword (2009, p. 328) elaborates:

An article that offers no suspense, no narrative arc, no sense of moving from $A$ to $B$, will not hold the reader's attention nearly as effectively as an article plotted, even at the most subtle level, like a good thriller (What will happen next?), or a mystery novel (What clues will the intrepid researcher/detective unearth?), or a Bildungsroman (What lessons will the protagonist learn along the way, and from whom?), or yes, even a fairytale or epic poem (Will good triumph over evil? Will the bad witch of administrative incompetence poison the idealistic young teacher's apple? Will we all live happily ever after, or do new challenges lurk on the horizon?)

Thus, academic research can be written like stories, but if the beginning gives away the outcome, the suspense is gone (see Wolff, 2007). The AAAJ article by Czarniawska (2010), called "Translation impossible? Accounting for a city project", is an example of an ongoing and interesting narrative where a road map paragraph would have been inappropriate. In her article, Czarniawska tells the story of an urban renewal project in Rome and how it evolves over time, continually making the reader wonder what comes next. The only detractor from the suspense of the story was the 'Abstract' because it was required by the publisher. Not surprisingly, the article is one of the shorter $A A A J$ publications. Again, not surprisingly, Barbara Czarniawska is renowned within the management and the accounting academic community for her ability to develop and utilise narratives. Her coauthored CPA article is another example of an article without the roadmap paragraph (see Pipan and Czarniawska, 2010).

\section{The literature review / hypotheses development}

Highly ranked journals are not likely to publish articles that merely replicate prior studies and find similar results. Such a study typically fails the novelty test. Furthermore, if a research article can be shown to link with a stream of literature, the relevance of the article and the likelihood that readers will be interested in the topic is established. Therefore, an overview of the literature needs to show 
both these links and what has not been examined (including deficiencies in prior methods and measures used) that will be addressed by the current article. The literature review is an integrated and synthesised summary focusing on the link with, and the deficiencies addressed by, the current study. Thus, it may be useful to ensure coverage of the relevant literature in the targeted journal.

Occasionally, an author will not develop a specific literature review in an article, for example, Stevens and Thevaranjan (2010, pp. 125-8) in their AOS article have an extended introduction to their article (over 2,800 words), which includes a discussion of the relevant literature on moral hazard and agency theory. In other cases authors use the literature review to develop specific hypotheses or research questions and at times even use the terms synonymously as in the Eldenburg et al. (2010, p. 226 and p. 235) AOS article. However, in general most articles we examined contain a section that can be clearly identified as a literature review or hypotheses development. Interestingly, AAAJ sections were considerably shorter at 1564 words on average than similar CPA and AOS sections at 2209 and 2394 words on average respectively.

\section{Context}

In some articles 'Context' is needed for the topic area, the particulars of the data or setting used, and/or some other unique aspect of the research project. For example, articles written to examine accounting history need to explain the context as the reader may not be familiar with the phenomenon being examined. Some examples of context are Arnaboldi and Lapsley's (2010, pp. 393-5) AAAJ article, which outlines in the section "Research context: asset management in local government" not only the importance of asset management in cities but also the challenges faced in performing the task, then explains more specifically how it applies to Scottish cities, the focus of the article. This is a good example of how a context section needs to bring the reader to the same place as the authors.

In AOS, Graham's (2010, pp. 26-32) article has a section called: “The beginnings of Canada's retirement income system", which traces the history of the development of the Canadian pensions system from its beginnings in 1907 until the origins of the present day system founded in 1951. Again, most readers would have little knowledge of pensions in the Canadian context and this section is helpful in immersing readers in the history of the phenomenon. Similarly, in CPA Killian (2010, pp. 713-5) has a section called "The background to "Shell to Sea"'" to introduce the context of oil production in a remote area of Ireland.

\section{Methodology sections}

In our framework we identified the two related sections of theory and method. It is important to note here the difference between the terms 'methodology' and 'method'. Guthrie et al. (2004 p. 417) describe the difference as follows:

Methods are the means whereby one collects and analyses data. Methodology refers to the philosophical issues which underlie those methods. The terms, thus, mean very different things - but journals vary in the extent to which they are exercised by that difference.

In our framework we have adapted the term methodology to include the theory employed as the framework for the analysis, and method to include the manner in which data is collected and analysed. For example, Rautiainen's (2010) AAAJ article features specific theory and method sections. In the theory section entitled "Contending institutional (and other) pressures" he explains 
how new institutional sociology is relevant to his study, while in the "Research method and data" he links the theory used to his choice of comparative case studies to analyse the data and present findings.

Again, we find that AOS articles have significantly higher word counts (Theory 2610 and Method 2204 words on average) than AAAJ articles (Theory 2037 and Method 1315 words on average) and CPA articles (Theory 1791 and Method 1020 words on average), but considering the generally longer length of $A O S$ articles, this is to be expected. It was again difficult to classify a number of sections in our analysis. For example, in AOS Cho et al. (2010) have a section called "Methods and analysis" that is in excess of 4,500 words and which includes a discussion of their findings as well.

Surprisingly, $20 A A A J, 25 A O S$ and $42 C P A$ articles did not have a specific 'Theory' section, especially since one of the criticisms of many academic articles is that they are too 'theoretical'. This is not to say that when a 'Theory' section was not outlined as part of the article's structure there was an absence of theory. A good example of this is the AAAJ article by Czarniawska (2010), mentioned before, that uses the concept of 'translation' from Latour associated with Actor-Network-Theory (Latour, 2005, p. 25). Czarniawska seems to expect that readers of her article are familiar with what 'translation' means and the theoretical context of its use. Similarly, Chenhall et al. (2010, pp. 739-40) use "Social capital within Bourdieu's concept of capital's" from Bourdieu's (1986) Theory of Practice, but initiate and link the discussion of their theoretical outlook with management control systems as part of the 'Literature review' section of their article. Again, the article is not devoid of theory; the authors just choose to represent the theory without using the signpost of a specific "Theory" section.

The 'Method' sections of AOS articles were more consistent with our model of article sections, with most articles, 31 of 43, having an identifiable 'Method' section. In this case the articles that commonly did not have a 'method' section were those of an historical nature, implying that the very nature of the topic made the method self-explanatory. In AOS, articles by Jones (2010), Carmona et al.(2010) and Spence (2010) fit this bill. Thus having an identifiable 'method' section appears an important structural element of empirical $A O S$ articles.

In $A A A J$ there were considerably fewer articles with a clearly identifiable 'Method' section with just over half, 20 of 39, of articles having sections signposted this way. The reason behind this appears to be a stronger emphasis on qualitative research based on understanding concepts from different theoretical contexts, for example Baker's (2010b) article that uses Habermasian and Foucauldian theoretical perspectives to discuss and contrast the concept of managerial capture. Similarly, theoretical articles by Nørreklit et al. (2010), Merino et al. (2010) and Burritt and Schaltegger (2010) exhibit similar characteristics. CPA had fewer articles, only 17 of 54, with a clearly signposted 'Method' section.

\section{The Back End}

In our framework we classify 'Results', 'Discussion' and the 'Conclusion' as elements of the back end of an article. Again the classification of these categories was made difficult by authors who used the terms together and/or combined them with other elements. Not surprisingly the $A O S$ articles again have significantly longer 'Results' (AAAJ 3438, AOS 4697, CPA 4066 words on average) and 'Discussion' sections (AAAJ 2714, AOS 5514, CPA 4450 words on average) in line with the overall 
length of AOS articles. On the other hand CPA had the smallest 'Conclusion' sections with 794 words on average followed by $A O S$ with 962 and $A A A J$ with 1034 words on average

It is in the back end of the articles analysed where we find the most consistency because all articles analysed signposted at least one identifiable "Results" and/or "Discussions" section. However this is also where we found the greatest variance in section length because the standard deviation for these sections was considerably higher than any other parts of the analysed articles. Some of these sections exceeded the length of some full articles. For example, the "Analysis/Discussion" section of Arnaboldi and Lapsley's (2010) AAAJ article reaches nearly 7,500 words. Similarly, in AOS the Gendron and Spira (2010) article has a section called 'Identity work patterns' that is over 11,000 words long. However, in defence of authors who were writing what appear to be complex articles, requiring a multifaceted analysis or discussion, these authors attempt to give more clarity to their articles by breaking their 'Analysis/Discussion' into smaller more manageable sub-sections, such as Carmona et al. (2010) who break it into five separate topics. Similarly in CPA, the Roslender and Hart (2010) article is an extensive discussion of customer accounting broken up into smaller sections.

\section{Supporting Evidence}

The last section of an article we analysed was 'supporting evidence', including appendices, notes, and acknowledgements. Again, in line with the overall length of AOS articles we found both the length of the 'Appendices' (AAAJ 692, AOS 1037, CPA 203 words on average), 'Notes' (AAAJ 540, AOS 794, CPA 527 words on average) and 'Acknowledgments' (AAAJ 69, AOS 88, CPA 48 words on average) sections to be greater in AOS than in CPA and AAAJ. From the perspective of 'Appendices' $A O S$ articles used these more often than $A A A J$ and CPA articles (AAAJ 7, AOS 13, CPA 5 instances). Typically in AOS, articles with appendices used them to present, for example, the details of questionnaires for quantitative articles (Henri and Journeault, 2010) and/or interview questions for qualitative articles (Mundy, 2010). Similarly, in AAAJ and CPA appendices were used to present information not deemed necessary in the body of the article. For example, Nørreklit et al. (2010) use an appendix to explain in detail "The roots of pragmatic constructivism" while Ferreira et al. (2010) disclose the questionnaire used in their research and Carrington (2010) presents extra detailed data on "audit wrongdoings".

As indicated before, $A A A J, A O S$ and CPA present their 'Notes' in different ways, with AAAJ using endnotes, but $A O S$ and $C P A$ using footnotes. Interestingly notes can constitute a considerable proportion of the word count of an article. In our analysis we have included notes in the total word count because these 'Notes' form an essential part of the message the author(s) is trying to get across. For example the in CPA the article by (Carrington, 2010) has 32 footnotes with 1137 words and the AOS article by Mennicken (2010) has 41 separate footnotes totalling over 2,800 words both representing approximately $11 \%$ of the total text. Similarly, in $A A A J$, Boedker (2010) used 41 endnotes totalling more than 3,800 words, comprising over $27 \%$ of the article's length. Such an extensive use of endnotes and footnotes can be questioned, because important information can normally be incorporated into the text, as Mikva (1984, pp. 647-8) put it somewhat humorously:

Let me start with the physical properties of footnotes and the difficulties they cause. By definition, a footnote is below the text to which it refers. (In other types of writing there is a device called "chapter notes" [or endnotes] which appear at the end of a writing; the problems with chapter notes are substantially similar to those with footnotes.) When reading a footnoted [article] one's eyes are constantly moving from text to 
footnotes and back again. The distraction and time waste are substantial. If footnotes were a rational form of communication, Darwinian selection would have resulted in the eyes being set vertically rather than on an inefficient horizontal plane.

\section{Visual Support - Tables, Plates, Figures, Exhibits and Equations}

We found the paucity of use of visual elements in the articles we examined interesting. Our analysis finds that there are few visual elements to help make sense of the story the author is trying to convey, with an average of three visual elements to each article. Here we find that accounting articles are at odds with other disciplines, such as the life sciences, in which articles make extensive use of visuals as Miller (1998, pp. 29-30) explains:

Visual elements in the form of figures, tables (and their glosses) occupy from one third to one half of the page of a typical research article, or report in the two most prestigious journals in science, Science and Nature. ...the visual elements in scientific papers and textbooks have increased in size and importance over the years. Not only do many scientists write their articles in order to highlight the visual but expert readers may 'read the visuals' before the rest of the article

Miller (1998, p. 30) explains that the use of visual elements, especially photographs, graphs and tables, gives the illusion that a reader has direct access to the data. Thus, not including visual elements in an article may detract from the message by leaving the reader distanced from the "harder facts" and thus the "proof" supporting the argument of the article (Latour, 1990). Qualitative articles may not have the opportunity to include as many tables, charts and/or pictures. Among our sample of articles, the photographs (plates) used by Czarniawska (2010) and McWatters and Lemarchand's (2010) extensive use of tables and figures in their respective AAAJ articles are good examples of the appropriate use of visual elements. They show that it is possible to use visual elements extensively, whereas most academic accounting authors choose not to. ${ }^{10} \mathrm{~A}$ picture is sometimes worth a thousand words and the use of more visuals could answer critics of lengthy and boring academic articles. The use of more visual elements could help reduce word counts and boredom and increase interest, understanding, and readability. Miller $(\underline{1998, \text { p. } 31)}$ ) builds on this point when he concludes that:

In short, visuals in academic articles provide data to convince the reader of the validity of the findings and allow the readers to see how the data were obtained and to interpret the data themselves. These visuals are impregnated with theory to show not only that they are anchored in the literature but that they have wider implications.

Thus, there is a solid argument for including more visuals in academic accounting articles.

\section{Referencing}

Referencing is an essential component of an academic article, but at times academics have been accused of over referencing themselves along with a tendency to over reference the journal in which the article appears, which we will refer to as author and journal self-referencing respectively (Rosenstreich and Wooliscroft, 2009, p. 229). First, in the articles we analysed we counted the number of references cited in each article and the results are shown in Figure 2. The AOS articles have on average more references than the $A A A J$ and $C P A$ articles. Interestingly, $A O S$ articles also had the greatest standard deviation with a score of 44.4 compared to 29.1 for $A A A J$ and 29.4 for CPA, indicating there are some $A O S$ articles with very high numbers of references, for example, Davison (2010) with 188 references and Kuasirikun and Constable (2010) with 257 references. We suspected that the reason for AOS papers' higher word count may be the greater number of references. 
However, correlation analysis resulted in an $r^{2}$ of 0.46 , thus number of references plays a role, but does not provide the full answer. To ensure that the two lengthy AOS papers mentioned above did not drive our result, we removed them from the data set and the resulting $r^{2}$ was actually lower, again suggesting other reasons for the extended AOS article length. At the other end of the spectrum, there are also some AOS articles with few citations, such as Bol and Moers (2010), with only 31 references in a 13,000+ word article. In $A A A J$, Samkin and Schneider (2010) had the most (139) references, and Czarniawska (2010) the least (15). For CPA Roslender and Hart (2010) had the most (139) and Harney (2010) the least (16).

\section{[Insert Figure 2 here]}

A wide variety of article types are published in interdisciplinary accounting journals and this may be the reason for such high and low citations. For example, on the low side the $A A A J$ article by Czarniawska (2010, p. 420) is crafted as a narrative to illustrate "the complexity of accounting for the city, on a specific example of an urban project in Rome". Her evidence is predominantly based on pictures rather than other academic articles. By contrast, the AOS article by Kuasirikun and Constable (2010) is written as a historical article about accounting in mid-19 ${ }^{\text {th }}$ century Thailand and relies entirely on previously published material for the evidence used in their article.

Academics tend to believe that it is necessary to reference the journal in which one is attempting to publish, otherwise the journal reviewers and editor(s) will take a dim view of the submitted paper and possibly reject the paper. There is some merit to this argument, because differing research traditions and journal culture dictate that an article relying on prior research published in a particular journal may be most suited for publication in that same journal. Thus, an editor may well question the suitability of a new submission if it does not cite prior research published in the journal.

Bearing this reasoning in mind, authors may scan articles published in the journal they are targeting for publication and cite as many as possible. Therefore, we examined the issue of journal selfreferencing and provide our results in Figure 3. The figure shows that $A O S$ articles on average journal self-reference around 2.7 times more than AAAJ and CPA articles, with 4.3 in AAAJ, 11.8 in AOS and 4.2 in CPA. AOS authors tend to include references to $A O S$ on a more frequent basis, at least during 2010. In percentage terms journal self-references represent $6.4 \%$ of $A A A J$ references, $13.2 \%$ of $A O S$ references, and $6.5 \%$ of CPA references. Although the number of AOS self-references are substantially higher, articles in all three journals still draw on a wide variety of sources.

\section{[Insert Figure 3 here]}

It is an open question whether journal self-referencing is an important issue. As a guideline, the Scopus citation ranking system allows a maximum of $33 \%$ of journal self-references in an article before they stop counting the number of references (González-Pereira et al., 2009, p. 5). All the articles in our sample comfortably fit under this limit, except for two AOS articles. Another often cited guideline (see Rosenstreich and Wooliscroft, 2009, p. 229) is Tahai and Meyer's (1999) study where they found an average $5 \%$ journal self-referencing rate with a range of 0 to $9 \%$ among top ranking North American management journals. On average, $A A A J$ and CPA articles fall inside this guideline, while AOS is above the guideline. 
As with references there is a wide disparity between different articles in the number of journal selfreferences used. The most journal self-references in $A A A J$ was in the articles by Samkin and Schneider (2010) and Brown (2010) each containing 14 (10\% and $11 \%$ respectively). In AOS the highest number of journal self-references belonged to the articles by Hall (2010) and Mundy (2010) with 37 each (33\% and 44\% respectively), while in CPA the Lehman (2010) article had 17 (14\%). On the other hand there were numerous articles with no journal self-references at all. AAAJ had seven (Boedker, 2010; Cristofoli et al., 2010; Czarniawska, 2010; Kornberger and Carter, 2010; Mc Watters and Lemarchand, 2010; Orij, 2010; Peng and Bewley, 2010), AOS had four (Bol and Moers, 2010; Gibbins et al., 2010; Koch and Schmidt, 2010; Norman et al., 2010) and CPA had eight (Andrew et al., 2010; Bessire and Onnée, 2010; Bettner et al., 2010; Harnev, 2010; Hikaka and Prebble, 2010; Iyoha and Oyerinde, 2010; James, 2010b; Sathe, 2010) showing that journal self-referencing is not a prerequisite for publication.

Similarly, we also examined the number of times authors cited their own work in an article. Some researchers are understandably critical of "author self-citations as a possible means of inflating citation rates and thus of strengthening the authors own positions in the scientific community" (Glänzel et al. (2004, p. 63). However, bibliometricians hold the view that a reasonable amount of author self-citation is an inevitable "part of scientific communication" (Glänzel et al., 2004, p. 63). In order to analyse author self-referencing we examined articles for references where any of the authors' prior papers were referenced ${ }^{11}$ and counted the number of articles referenced and the number of instances their articles were referenced in the article's text. As shown in Table 6 AAAJ authors self-cited their prior publications ${ }^{12}$ most, with an average of 4.1 times per article, compared to AOS with 3.3 times and CPA with 3.1 times. On the other hand AOS authors cited their work more frequently in text with 7.3 incidences of their articles on average, compared to AAAJ with 7.1 and CPA with 5.9 incidences on average each.

\section{[Insert Table 6 here]}

The question is whether these rates of author self-citations are excessive? This is problematic because no 'reasonable' limit has been set because of the issues raised above, however in the social sciences, of which accounting is part, the rates of author self-citations tend to be "less dramatic" than in other fields (Glänzel et al., 2004, p. 69). As shown in Table 6, we find that the percentage of references that are author self-citations are lower than the percentages of journal self-citations, with $A A A J$ at $6.0 \%$ (author self-citation vs. $6.4 \%$ journal self-citation), $A O S$ at $3.7 \%$ (vs. $13.2 \%$ ) and CPA at $4.9 \%$ (vs. 6.5\%). Thus, we conclude that author self-citation is, on average, not excessive in these journals. However, there are articles with high levels of author self-citations. In AAAJ, Burritt and Schaltegger (2010) cited 14 of their own articles 39 times in the text; in AOS, Gray (2010) cited 23 of his articles 43 times in the text; while in CPA, Lehman (2010) cited 13 of his articles 33 times in the text. These individuals can be argued to be leading scholars in their respective fields and therefore the number of author self-citations may well be justified. There were also numerous articles with no author self-citations with AAAJ having four (Agyemang, 2010; Baker, 2010b; Cordery et al., 2010; Orij, 2010), AOS eight (Bezemer, 2010; Bol and Moers, 2010; Jørgensen and Messner, 2010; Koch and Schmidt, 2010; Kornberger et al., 2010; Mundy, 2010; Norman et al., 2010; O'Regan, 2010), and CPA having ten (Asenova and Beck, 2010; Bessire and Onnée, 2010; Christopher, 2010; Everett and Friesen, 2010; James, 2010b; Killian, 2010; Marriott, 2010; Mete et al., 2010; Noël 
et al., 2010). Thus $A A A J, A O S$ and CPA show incidences of high and no author self-citations in line with the observations of Glänzel et al. (2004).

By and large, both journal self-citation and author self-citation appear to be relatively small. For ease of comparison we have summarised these findings in Table 7. The average total citations, journal self-citations, and author self-citations were: $67.6,4.3$, and 3.1 for $A A A J ; 89.1,11.8$, and 3.2 for $A O S$; and $64.2,4.2$, and 3.1 for CPA. The one figure that stands out is the average of 11.8 journal selfcitations for $A O S$ articles.

[Insert Table 7 here]

\section{Conclusion}

In this paper we have discussed the increased pressure on accounting academics to publish in highly ranked journals and provide insight into the construction of articles published in three leading academic accounting journals, namely $A A A J, A O S$ and CPA. We discussed the attributes and construction of published interdisciplinary academic accounting articles. This could inform the approach of both emerging and experienced scholars, contribute to a discussion of ways authors might adapt their approach to writing, and potentially influence aspects of future research outputs.

The first contribution of our paper is to provide insight into the construction of accounting academic articles in highly ranked interdisciplinary journals. In particular, we have introduced the simplified concept of the five distinct major parts of an article being 'Introduction', 'Methodology', 'The Back End', 'Supporting evidence' and 'References' along with their contributing minor sections. Our analysis of the major parts shows that it is not necessary to have all of the individual sections, or elements, as each article is unique. The basic elements can vary and can even be absent, for example, there are published articles without a specific 'Method' section or a 'Conclusions' section. Apparently, there is no standard article structure, for example, Czarniawska's (2010) narrative AAAJ article using a photo as evidence is unique, interesting, entertaining, pushes the boundaries, and challenges some taken-for-granted views of how an accounting academic article should be constructed.

A second contribution of this paper is to discuss some of the taken-for-granted aspects of articles such as the use of the first or third person; the use of road map paragraphs; and the paucity of use of figures and illustrations. We conclude that all of these elements have their place and if used effectively can add to the quality of an article. However, if these attributes are used inappropriately, for example, because of personal preference, it can have the opposite effect, namely of reducing quality. Our evidence has provided examples where these attributes could have been used (or not used) more effectively. For example, the use of a road map paragraph to purposely outline the content and argument of an article can be an effective tool provided it was the authors' intention to do so, while other authors who want to deliver a more narrative suspenseful story would purposely omit it. The article's message should be the guide and not personal preferences.

In line with our second research question we can now reflect more on the apparent rules and outline ways that journal editors, reviewers and authors can challenge some of the prevailing taken-forgranted beliefs and attitudes. Our sample included mostly qualitative articles, articles of varying lengths, and articles with many references and others with none. Apparently, there are no hard and fast rules, as long as the article conveys the message. In this light, we suggest that reviewers and 
editors remain receptive to papers that do not comply with certain preconceived rules (e.g., papers written in the third person and in an abstract style). Our evidence shows it is possible to break some of the 'taboos' and still publish in a high ranking interdisciplinary accounting journal. More unorthodox articles can perhaps dispel some of the criticisms directed towards academic writing.

In our view, academic writing can be improved by treating it as a craft that needs to be honed over time. Academics need to develop their writing skills in order to publish in quality accounting journals such as $A A A J, A O S$ and CPA. While it is true that most of the articles published in highly ranked journals are authored by academics already prominent in accounting academia, a likely contributing factor is that these authors have completed their writing apprenticeships. Nevertheless, our analysis shows that $A A A J, A O S$ and CPA publish a high proportion of first time sole authored articles, as well as articles where a first time author co-authors with a previously published author. We conclude that the gates are not closed to anyone, but that inherent article qualities are more important than the prominence of the author(s) in the acceptance probability of a paper. Returning to writing skills, we echo Sword (2009) in advocating challenging the boundaries of academic writing style. We recommend that all authors continue to develop novel, engaging, and interesting writing with the potential to appeal to a wider audience than accounting academics alone.

Academic articles continue to be criticised for being too boring and abstract. Academic articles are also getting longer (Ellison, 2002). A sobering insight into article length is provided by comparing the first edition of $A O S$ where a total of ten original research articles took up only 93 pages with issue eight of $A O S$ in 2010, which contained only four articles that took up 72 pages. The taken-forgranted article length appears to have changed significantly since the 1976 AOS first edition, but the question is why? One answer to this question may be that technological developments of the last few decades have impacted authors' and publishers' ability to produce greater volumes of academic prose. One only needs to reflect that AOS emerged at the same time as the personal computer, while $A A A J$ emerged along with word processing software. As Guthrie and Parker $(\underline{2012, \text { p. } 7)}$ lament, for the first edition of $A A A J$ "only 100 hard copies of $A A A J$ were printed, many of these going to the $A A A J$ EB [editorial board] members, of whom there were 32". They add further "How different [it is] today at the beginning of $A A A J^{\prime}$ 's twenty-fifth year in 2012. Our publisher Emerald has moved from printed to electronic means for both submissions and access to papers published in $A A A J "$.

Technology may facilitate a continued growth in article length. Should editors allow this trend to continue, then existing page limitations per volume of printed journals limits the opportunity for many accounting scholars to publish. On the other hand, technology also facilitates newer publication models, such as only publishing in electronic format, fee for publication, and open (free) access publishing in which technology is utilised to allow for more academic work to be disseminated. Provided these models continue to uphold the ethics of publishing academically sound, novel, quality material they may in future threaten the current, sometimes controversial, model of academic publishing. Arguably, this could create information overload because, as Lanham (2006, p. xi) points out, we are transforming from a "knowledge economy" to an "attention economy" where there is an oversupply of information, but attention is in short supply. Thus, the future success of authors and journals appears to be grounded in their ability to get others to pay attention to their work. 
'Getting attention' can be measured by the number and quality of citations authors and journals receive. It is worth noting that the prevalence of citations can vary among different accounting research traditions, with accounting history or accounting education reportedly getting fewer citations. This makes comparison between authors and across journals with different subject specialisms problematic. Nevertheless, as outlined in our introduction, there has been a shift towards citation data as one of the litmus tests of quality. We argue that it is likely that citation data will become even more important in the future and compete with peer based journal ranking lists. We base this argument on the growing prevalence and importance of citation data available through the likes of Scopus, Google Scholar, Harzing's Publish or Perish, and Microsoft Academic Search. The influence of these citation indexes and citation based searches is made possible by the same technological advances pushing the boundaries of academic publishing. These citation indexes now facilitate the assessment of individual impact (as opposed to journal impact). Thus, these tools may increasingly become the accepted way to measure academic success (and arguably quality) (see Moosa, 2011). Indeed, Gendron (2008), while lamenting the iniquities in these developments, argues that even academics who are sensitive to the negative consequences and iniquities of rankings and other short-cuts that facilitate comparison, tend to perpetuate the use of these methods of research assessment.

We base our findings on our interpretation of research articles published during 2010 in three highly ranked interdisciplinary accounting journals, $A A A J, A O S$ and $C P A$. In doing so, we hope to have provided practical guidance for authors in preparing papers for publication in these journals. More specifically, we also recommend this paper as a "must read" for emerging scholars and higher degree research students because it emphasises the amount of work, diligence and skill that goes into writing an article. An understanding how published articles have been constructed equips them with the skeleton which they must 'flesh out', based on their own craft of research and writing, not forgetting to leave a little of their own touch or 'soul' behind as well.

\section{References}

Agyemang, G. (2010), "Accounting for needs? Formula funding in the UK schools sector", Accounting, Auditing \& Accountability Journal, Vol 23 No 1, pp. 82-110.

Andrew, J., Kaidonis, M. A. and Andrew, B. (2010), "Carbon tax: Challenging neoliberal solutions to climate change", Critical Perspectives on Accounting, Vol 21 No 7, pp. 611-618.

Arnaboldi, M. and Azzone, G. (2010), "Constructing performance measurement in the public sector", Critical Perspectives on Accounting, Vol 21 No 4, pp. 266-282.

Arnaboldi, M. and Lapsley, I. (2010), "Asset management in cities: Polyphony in action?", Accounting, Auditing \& Accountability Journal, Vol 23 No 3, pp. 392-419.

Asenova, D. and Beck, M. (2010), "Crucial silences: When accountability met PFI and finance capital", Critical Perspectives on Accounting, Vol 21 No 1, pp. 1-13.

Australian Research Council (ARC) (2011), ERA 2012 Submission Guidelines: Excellence in Research Australia 2012, Australian Government, Canberra.

Baker, M. (2010a), "Office window", Accounting, Auditing \& Accountability Journal, Vol 23 No 8, pp. 1063-1063.

Baker, M. (2010b), "Re-conceiving managerial capture", Accounting, Auditing \& Accountability Journal, Vol 23 No 7, pp. 847-867.

Ball, A. and Craig, R. (2010), "Using neo-institutionalism to advance social and environmental accounting", Critical Perspectives on Accounting, Vol 21 No 4, pp. 283-293. 
Ballas, A. and Theoharakis, V. (2003), "Exploring diversity in accounting through faculty journal perceptions", Contemporary Accounting Research, Vol 20 No 4, pp. 619-44.

Beattie, V. and Emmanuel, C. (2008), "The British Accounting Review review process - Evidence from 1997 to 2006", The British Accounting Review, Vol 40 No 3, pp. 199-206.

Beattie, V. and Goodacre, A. (2004), "Publishing patterns within the UK accounting and finance academic community", The British Accounting Review, Vol 36 No 1, pp. 7-44.

Bédard, J. and Gendron, Y. (2003), "Qualitative research on accounting: Some thoughts on what occurs behind the scene", in C. Humphrey and B. H. K. Lee (Eds), The Real Life Guide to Accounting Research: A Behind-the-Scenes View of Using Qualitative Research Methods, Elsevier, Amsterdam, pp. 192-206.

Bessire, D. and Onnée, S. (2010), "Assessing corporate social performance: Strategies of legitimation and conflicting ideologies", Critical Perspectives on Accounting, Vol 21 No 6, pp. 445-467.

Bettner, M. S., Frandsen, A.-C. and McGoun, E. G. (2010), "Listening to accounting", Critical Perspectives on Accounting, Vol 21 No 4, pp. 294-302.

Beyer, B., Herrmann, D., Meek, G. K. and Rapley, E. T. (2010), "What it means to be an accounting professor: A concise career giuide for doctoral students in accounting", Issues in Accounting Education, Vol 25 No 2, pp. 227-44.

Bezemer, D. J. (2010), "Understanding financial crisis through accounting models", Accounting, Organizations and Society, Vol 35 No 7, pp. 676-688.

Boedker, C. (2010), "Ostensive versus performative approaches for theorising accounting-strategy research", Accounting, Auditing \& Accountability Journal, Vol 23 No 5, pp. 595-625.

Bol, J. C. and Moers, F. (2010), "The dynamics of incentive contracting: The role of learning in the diffusion process", Accounting, Organizations and Society, Vol 35 No 8, pp. 721-736.

Bourdieu, P. (1986), "The forms of capital", in J. G. Richardson (Ed), Handbook of Theory and Practice for the Sociology of Education, Greenwood, New York, pp. pp. 241-258.

Brick, J. (2005), Writing Academic English. mimeo, Macquarie University, pp. 11.

Brown, J. (2010), "Accounting and visual cultural studies: Potentialities, challenges and prospects", Accounting, Auditing \& Accountability Journal, Vol 23 No 4, pp. 482-505.

Burritt, R. L. and Schaltegger, S. (2010), "Sustainability accounting and reporting: Fad or trend?", Accounting, Auditing \& Accountability Journal, Vol 23 No 7, pp. 829-846.

Carmona, S. (2011), "In pursuance of successful research", European Accounting Review, Vol 20 No 1, pp. 1-5.

Carmona, S., Donoso, R. and Walker, S. P. (2010), "Accounting and international relations: Britain, Spain and the Asiento treaty", Accounting, Organizations and Society, Vol 35 No 2, pp. 252273.

Carrington, T. (2010), "An analysis of the demands on a sufficient audit: Professional appearance is what counts!", Critical Perspectives on Accounting, Vol 21 No 8, pp. 669-682.

Chenhall, R. H., Hall, M. and Smith, D. (2010), "Social capital and management control systems: A study of a non-government organization", Accounting, Organizations and Society, Vol 35 No 8, pp. 737-56.

Cho, C. H., Roberts, R. W. and Patten, D. M. (2010), "The language of US corporate environmental disclosure", Accounting, Organizations and Society, Vol 35 No 4, pp. 431-443.

Christensen, M. and Skærbæk, P. (2010), "Consultancy outputs and the purification of accounting technologies", Accounting, Organizations and Society, Vol 35 No 5, pp. 524-545.

Christopher, J. (2010), "Corporate governance-A multi-theoretical approach to recognizing the wider influencing forces impacting on organizations", Critical Perspectives on Accounting, Vol 21 No 8, pp. 683-695.

Cianci, A. M. and Kaplan, S. E. (2010), "The effect of CEO reputation and explanations for poor performance on investors' judgments about the company's future performance and management", Accounting, Organizations and Society, Vol 35 No 4, pp. 478-495. 
Cooper, C., Danson, M., Whittam, G. and Sheridan, T. (2010), "The neoliberal project-Local taxation intervention in Scotland", Critical Perspectives on Accounting, Vol 21 No 3, pp. 195-210.

Cordery, C., Baskerville, R. and Porter, B. (2010), "Control or collaboration?: Contrasting accountability relationships in the primary health sector", Accounting, Auditing \& Accountability Journal, Vol 23 No 6, pp. 793-813.

Cristofoli, D., Ditillo, A., Liguori, M., Sicilia, M. and Steccolini, I. (2010), "Do environmental and task characteristics matter in the control of externalized local public services?: Unveiling the relevance of party characteristics and citizens' offstage voice", Accounting, Auditing \& Accountability Journal, Vol 23 No 3, pp. 350-372.

Czarniawska, B. (2010), "Translation impossible? Accounting for a city project", Accounting, Auditing \& Accountability Journal, Vol 23 No 3, pp. 420-437.

Davison, J. (2010), "[In]visible [in]tangibles: Visual portraits of the business élite", Accounting, Organizations and Society, Vol 35 No 2, pp. 165-183.

Eldenburg, L., Soderstrom, N., Willis, V. and Wu, A. (2010), "Behavioral changes following the collaborative development of an accounting information system", Accounting, Organizations and Society, Vol 35 No 2, pp. 222-237.

Ellison, G. (2002), "Evolving standards for academic publishing: A q-r theory", Journal of Political Economy, Vol 110 No 5, pp. 994-1034.

Englebrecht, T. D., Hanke, S. A. and Kuang, Y. (2008), "An assessment of patterns of co-authorship for academic accountants within premier journals: Evidence from 1979-2004", Advances in Accounting, Vol 24 No 2, pp. 172-181.

Everett, J. and Friesen, C. (2010), "Humanitarian accountability and performance in the Théâtre de l'Absurde", Critical Perspectives on Accounting, Vol 21 No 6, pp. 468-485.

Ferreira, A., Moulang, C. and Hendro, B. (2010), "Environmental management accounting and innovation: An exploratory analysis", Accounting, Auditing \& Accountability Journal, Vol 23 No 7, pp. 920-948.

Fogarty, T. J. and Jonas, G. A. (2010), "The hand that rocks the cradle: Disciplinary socialization at the American Accounting Association's Doctoral Consortium", Critical Perspectives on Accounting, Vol 21 No 4, pp. 303-317.

Frow, N., Marginson, D. and Ogden, S. (2010), "'Continuous' budgeting: Reconciling budget flexibility with budgetary control", Accounting, Organizations and Society, Vol 35 No 4, pp. 444-461.

Gendron, Y. (2008), "Constituting the academic performer: The spectre of superficiality and stagnation in scademia", European Accounting Review, Vol 17 No 1, pp. 97-127.

Gendron, Y. and Spira, L. F. (2010), "Identity narratives under threat: A study of former members of Arthur Andersen", Accounting, Organizations and Society, Vol 35 No 3, pp. 275-300.

Gibbins, M., McCracken, S. and Salterio, S. E. (2010), "The auditor's strategy selection for negotiation with management: Flexibility of initial accounting position and nature of the relationship", Accounting, Organizations and Society, Vol 35 No 6, pp. 579-595.

Glänzel, W., Thijs, B. and Schlemmer, B. (2004), "A bibliometric approach to the role of author selfcitations in scientific communication", Scientometrics, Vol 59 No 1, pp. 63-77.

Glover, S. M., Prawitt, D. F. and Wood, D. A. (2006), "Publication records of faculty promoted at the top 75 accounting research programs", Issues in Accounting Education, Vol 21 No 3, pp. 195218.

González-Pereira, B., Guerrero-Bote, V. P. and Moya-Anegón, F. (2009), "The SJR indicator: A new indicator of journals' scientific prestige." Retrieved 9 October 2011, Available at; http://arxiv.org/pdf/0912.4141v1.

Graham, C. (2010), "Accounting and the construction of the retired person", Accounting, Organizations and Society, Vol 35 No 1, pp. 23-46.

Gray, R. (2010), "Is accounting for sustainability actually accounting for sustainability ... and how would we know? An exploration of narratives of organisations and the planet", Accounting, Organizations and Society, Vol 35 No 1, pp. 47-62. 
Guidi, M. G. D., Hillier, J. and Tarbert, H. (2010), "Successfully reshaping the ownership relationship by reducing 'moral debt' and justly distributing residual claims: The cases from Scott Bader Commonwealth and the John Lewis Partnership", Critical Perspectives on Accounting, Vol 21 No 4, pp. 318-328.

Guthrie, J. and Parker, L. (2006), "Editorial: The coming out of accounting research specialisms", Accounting, Auditing \& Accountability Journal, Vol 19 No 1, pp. 5-16.

Guthrie, J., Parker, L. and Gray, R. (2004), "Requirements and understandings for publishing academic research: An insider view", in C. Humphrey and W. Lee (Eds), The Real Life Guide to Accounting Research: A Behind-the-scenes View of Using Qualitative Research Methods, Elsevier, Amsterdam, pp. 411-32.

Guthrie, J. and Parker, L. D. (2012), "Reflections and projections: 25 years of interdisciplinary perspectives on accounting, auditing and accountability research", Accounting, Auditing \& Accountability Journal, Vol 25 No 1, pp. 6-26.

Hall, M. (2010), "Accounting information and managerial work", Accounting, Organizations and Society, Vol 35 No 3, pp. 301-315.

Hanlon, G. (2010), "Knowledge, risk and Beck: Misconceptions of expertise and risk", Critical Perspectives on Accounting, Vol 21 No 3, pp. 211-220.

Harney, S. (2010), "Accounting, risk, and revolution", Critical Perspectives on Accounting, Vol 21 No $1, \mathrm{pp} .14-17$.

Harzing, A.-W. (2010), Publish or Perish, Tarma Software Research Pty Ltd, Melbourne.

Haynes, K. (2010), "Other lives in accounting: Critical reflections on oral history methodology in action", Critical Perspectives on Accounting, Vol 21 No 3, pp. 221-231.

Heck, J. L. and Bremser, W. G. (1986), "Six decades of The Accounting Review: A Summary of Author and institutional contributors", Accounting Review, Vol 61 No 4, pp. 735.

Heck, J. L. and Jensen, R. E. (2007), "An analysis of the evolution of research contributions by the Accounting Review, 1926-2005", Accounting Historians Journal, Vol 34 No 2, pp. 109-41.

Henri, J.-F. and Journeault, M. (2010), "Eco-control: The influence of management control systems on environmental and economic performance", Accounting, Organizations and Society, Vol 35 No 1, pp. 63-80.

Hikaka, G. and Prebble, J. (2010), "Autopoiesis and general anti-avoidance rules", Critical Perspectives on Accounting, Vol 21 No 7, pp. 545-559.

Hopwood, A. (2008), "Changing pressures on the research process: On trying to research in an age when curiosity is not enough", European Accounting Review, Vol 17 No 8, pp. 87-96.

Howard, T. P. and Stout, D. E. (2006), "Reasons accounting case/instructional resource papers are rejected for publication", Journal of Accounting Education, Vol 24 No 1, pp. 1-15.

Iyoha, F. O. and Oyerinde, D. (2010), "Accounting infrastructure and accountability in the management of public expenditure in developing countries: A focus on Nigeria", Critical Perspectives on Accounting, Vol 21 No 5, pp. 361-373.

James, K. (2010a), "“Who am I? Where are we? Where do we go from here?" Marxism, voice, representation, and synthesis", Critical Perspectives on Accounting, Vol 21 No 8, pp. 696710.

James, M. (2010b), "Humpty Dumpty's guide to tax law: Rules, principles and certainty in taxation", Critical Perspectives on Accounting, Vol 21 No 7, pp. 573-583.

Jones, M. J. (2010), "Sources of power and infrastructural conditions in medieval governmental accounting", Accounting, Organizations and Society, Vol 35 No 1, pp. 81-94.

Jørgensen, B. and Messner, M. (2010), "Accounting and strategising: A case study from new product development", Accounting, Organizations and Society, Vol 35 No 2, pp. 184-204.

Josiah, J., Burton, B., Gallhofer, S. and Haslam, J. (2010), "Accounting for privatisation in Africa? Reflections from a critical interdisciplinary perspective", Critical Perspectives on Accounting, Vol 21 No 5, pp. 374-389. 
Killian, S. (2010), "“No accounting for these people": Shell in Ireland and accounting language", Critical Perspectives on Accounting, Vol 21 No 8, pp. 711-723.

Koch, C. and Schmidt, C. (2010), "Disclosing conflicts of interest - Do experience and reputation matter?", Accounting, Organizations and Society, Vol 35 No 1, pp. 95-107.

Kornberger, M. and Carter, C. (2010), "Manufacturing competition: How accounting practices shape strategy making in cities", Accounting, Auditing \& Accountability Journal, Vol 23 No 3, pp. 325-349.

Kornberger, M., Carter, C. and Ross-Smith, A. (2010), "Changing gender domination in a Big Four accounting firm: Flexibility, performance and client service in practice", Accounting, Organizations and Society, Vol 35 No 8, pp. 775-791.

Kuasirikun, N. and Constable, P. (2010), "The cosmology of accounting in mid 19th-century Thailand", Accounting, Organizations and Society, Vol 35 No 6, pp. 596-627.

Lanham, R. A. (2006), The Economics of Attention: , University of Chicago Press, Chicago.

Lapsley, I. and Giordano, F. (2010), "Congestion charging: A tale of two cities", Accounting, Auditing \& Accountability Journal, Vol 23 No 5, pp. 671-698.

Latour, B. (1990), "Drawing things together", in M. Lynch and S. Woolgar (Eds), Representation in Scientific Practice, The MIT Press, Cambridge, MA, pp. 1-68.

Latour, B. (2005), Reassembling the Social. An Introduction to Actor-network Theory, Oxford University Press, Oxford.

Laughlin, R. (2010), "A comment on "Towards a paradigmatic foundation for accounting practice"”, Accounting, Auditing \& Accountability Journal, Vol 23 No 6, pp. 759-763.

Lehman, G. (2010), "Perspectives on accounting, commonalities \& the public sphere", Critical Perspectives on Accounting, Vol 21 No 8, pp. 724-738.

Levinson, A. R. (2009), "Enhancing Roadmap Paragraphs - Legal Writing Tip", Retrieved 6 July 2011, http://www.law.louisville.edu/node/3742.

Mäkelä, H. and Näsi, S. (2010), "Social responsibilities of MNCs in downsizing operations: A Finnish forest sector case analysed from the stakeholder, social contract and legitimacy theory point of view", Accounting, Auditing \& Accountability Journal, Vol 23 No 2, pp. 149-174.

Marriott, L. (2010), "Power and ideas: The development of retirement savings taxation in Australasia", Critical Perspectives on Accounting, Vol 21 No 7, pp. 597-610.

Mc Watters, C. S. and Lemarchand, Y. (2010), "Accounting as story telling: Merchant activities and commercial relations in eighteenth century France", Accounting, Auditing \& Accountability Journal, Vol 23 No 1, pp. 14-54.

McKinlay, A. and Pezet, E. (2010), "Accounting for Foucault", Critical Perspectives on Accounting, Vol 21 No 6, pp. 486-495.

Mennicken, A. (2010), "From inspection to auditing: Audit and markets as linked ecologies", Accounting, Organizations and Society, Vol 35 No 3, pp. 334-359.

Merino, B. D., Mayper, A. G. and Tolleson, T. D. (2010), "Neoliberalism, deregulation and SarbanesOxley: The legitimation of a failed corporate governance model", Accounting, Auditing \& Accountability Journal, Vol 23 No 6, pp. 774-792.

Mete, P., Dick, C. and Moerman, L. (2010), "Creating institutional meaning: Accounting and taxation law perspectives of carbon permits", Critical Perspectives on Accounting, Vol 21 No 7, pp. 619-630.

Mikva, A. J. (1984), "Goodbye to footnotes", University of Colorado Law Review, Vol 1984-1985 No 3, pp. 647-54.

Miller, T. (1998), "Visual persuasion: A comparison of visuals in academic texts and the popular press", English for Specific Purposes, Vol 17 No 1, pp. 29-46.

Moosa, I. (2011), "The demise of the ARC journal ranking scheme: An ex post analysis of the accounting and finance journals", Accounting \& Finance, Vol 51 No 3, pp. 809-36.

Mosteller, F., Nave, B. and Miech, E. J. (2004), "Why we need a structured abstract in education research", Educational Researcher, Vol 33 No 1, pp. 29-34. 
Mundy, J. (2010), "Creating dynamic tensions through a balanced use of management control systems", Accounting, Organizations and Society, Vol 35 No 5, pp. 499-523.

Noël, C., Ayayi, A. G. and Blum, V. (2010), "The European Union's accounting policy analyzed from an ethical perspective: The case of petroleum resources, prospecting and evaluation", Critical Perspectives on Accounting, Vol 21 No 4, pp. 329-341.

Norman, C. S., Rose, A. M. and Rose, J. M. (2010), "Internal audit reporting lines, fraud risk decomposition, and assessments of fraud risk", Accounting, Organizations and Society, Vol 35 No 5, pp. 546-557.

Nørreklit, H., Nørreklit, L. and Mitchell, F. (2010), "Towards a paradigmatic foundation for accounting practice", Accounting, Auditing \& Accountability Journal, Vol 23 No 6, pp. 733-758.

Northcott, D. and Linacre, S. (2010), "Producing spaces for academic discourse: The impact of research assessment exercises and journal quality rankings", Australian Accounting Review, Vol 20 No 1, pp. 38-54.

O'Donnell, E. and Prather-Kinsey, J. (2010), "Nationality and differences in auditor risk assessment: A research note with experimental evidence", Accounting, Organizations and Society, Vol 35 No 5, pp. 558-564.

O'Regan, P. (2010), “'A dense mass of petty accountability': Accounting in the service of cultural imperialism during the Irish Famine, 1846-1847", Accounting, Organizations and Society, Vol 35 No 4, pp. 416-430.

Orij, R. (2010), "Corporate social disclosures in the context of national cultures and stakeholder theory", Accounting, Auditing \& Accountability Journal, Vol 23 No 7, pp. 868-889.

Parker, L. D. and Guthrie, J. (2010), "Business schools in an age of globalization", Accounting, Auditing \& Accountability Journal, Vol 23 No 1, pp. 5-13.

Peng, S. and Bewley, K. (2010), "Adaptability to fair value accounting in an emerging economy: A case study of China's IFRS convergence", Accounting, Auditing \& Accountability Journal, Vol 23 No 8, pp. 982-1011.

Pfeffer, J. (2007), "A modest proposal: How we might change the process and product of managerial research", Academy of Management Journal, Vol 50 No 6, pp. 1334-1345.

Pipan, T. and Czarniawska, B. (2010), "How to construct an actor-network: Management accounting from idea to practice", Critical Perspectives on Accounting, Vol 21 No 3, pp. 243-251.

Primack, R. B. (2009), "Why did we reject your paper?", Biological Conservation, Vol 142 No 8, pp. 1559.

Rahaman, A. S. (2010), "Critical accounting research in Africa: Whence and whither", Critical Perspectives on Accounting, Vol 21 No 5, pp. 420-427.

Rautiainen, A. (2010), "Contending legitimations: Performance measurement coupling and decoupling in two Finnish cities", Accounting, Auditing \& Accountability Journal, Vol 23 No 3, pp. 373-391.

Rosenstreich, D. and Wooliscroft, B. (2009), "Measuring the impact of accounting journals using Google Scholar and the g-index", The British Accounting Review, Vol 41 No 4, pp. 227-239.

Roslender, R. and Hart, S. J. (2010), "Taking the customer into account: Transcending the construction of the customer through the promotion of self-accounting", Critical Perspectives on Accounting, Vol 21 No 8, pp. 739-753.

Samkin, G. and Schneider, A. (2010), "Accountability, narrative reporting and legitimation: The case of a New Zealand public benefit entity", Accounting, Auditing \& Accountability Journal, Vol 23 No 2, pp. 256-289.

Sathe, R. S. (2010), "CPA licensure without examination: Legitimation and resistance", Critical Perspectives on Accounting, Vol 21 No 6, pp. 496-508.

Schultz Jr, J. J., Bierstaker, J. L. and O'Donnell, E. (2010), "Integrating business risk into auditor judgment about the risk of material misstatement: The influence of a strategic-systems-audit approach", Accounting, Organizations and Society, Vol 35 No 2, pp. 238-251. 
Sikka, P. and Willmott, H. (2010), "The dark side of transfer pricing: Its role in tax avoidance and wealth retentiveness", Critical Perspectives on Accounting, Vol 21 No 4, pp. 342-356.

Spence, C. (2010), "Accounting for the dissolution of a nation state: Scotland and the Treaty of Union", Accounting, Organizations and Society, Vol 35 No 3, pp. 377-392.

Spence, C., Husillos, J. and Correa-Ruiz, C. (2010), "Cargo cult science and the death of politics: A critical review of social and environmental accounting research", Critical Perspectives on Accounting, Vol 21 No 1, pp. 76-89.

Stevens, D. E. and Thevaranjan, A. (2010), "A moral solution to the moral hazard problem", Accounting, Organizations and Society, Vol 35 No 1, pp. 125-139.

Stout, D. E., Rebele, J. E. and Howard, T. P. (2006), "Reasons research papers are rejected at accounting education journals", Issues in Accounting Education, Vol 21 No 2, pp. 81-98.

Sword, H. (2007), The Writer's Diet, Pearson Education New Zealand, Rosedale, NZ.

Sword, H. (2009), "Writing higher education differently: A manifesto on style", Studies in Higher Education, Vol 34 No 3, pp. 319-336.

Tahai, A. and Meyer, M. J. (1999), "A revealed preference study of management journals' direct influences", Strategic Management Journal, Vol 20 No 3, pp. 279-296.

Toms, J. S. (2010a), "Calculating profit: A historical perspective on the development of capitalism", Accounting, Organizations and Society, Vol 35 No 2, pp. 205-221.

Toms, J. S. (2010b), "The labour theory of value, risk and the rate of profit", Critical Perspectives on Accounting, Vol 21 No 1, pp. 96-103.

Toms, S. (2010c), "Value, profit and risk: Accounting and the resource-based view of the firm", Accounting, Auditing \& Accountability Journal, Vol 23 No 5, pp. 647-670.

University of Sydney. (2011), "Academic Promotions Policy", Retrieved 16 May 2011, http://sydney.edu.au/provost/docs/2011 policy/Promotions policy 2011.pdf.

University of Sydney (UOS). (2012), "Final Change Plan", Retrieved 17 March 2012, http://sydney.edu.au/staff/leadership/budget/final change plan.shtml.

van Veen-Dirks, P. (2010), "Different uses of performance measures: The evaluation versus reward of production managers", Accounting, Organizations and Society, Vol 35 No 2, pp. 141-164.

Wolff, J. (2007), "Literary boredom", Retrieved July 11 2011, http://www.guardian.co.uk/education/2007/sep/04/highereducation.news.

Young, J. J. and Williams, P. F. (2010), "Sorting and comparing: Standard-setting and "ethical" categories", Critical Perspectives on Accounting, Vol 21 No 6, pp. 509-521. 


\begin{tabular}{|c|c|c|c|c|c|c|c|c|}
\hline Source title & $\begin{array}{c}\text { Scopus } \\
\text { SNIP } \\
2010\end{array}$ & $\begin{array}{c}\text { Scopus } \\
\text { SJR } \\
2010\end{array}$ & $\begin{array}{c}\text { Rank } \\
\text { (SJR } \\
\text { 2010) } \\
\end{array}$ & $\begin{array}{l}\text { Rank } \\
\text { (SNIP } \\
\text { 2010) } \\
\end{array}$ & $\begin{array}{c}\text { Rank } \\
\text { g } \\
\text { Index }\end{array}$ & $\begin{array}{c}\text { ABS } \\
(2010)\end{array}$ & $\begin{array}{c}\text { ERA } \\
(2010)\end{array}$ & $\begin{array}{c}\text { Moosa } \\
(2011) \\
h \\
\text { index }\end{array}$ \\
\hline Abacus & 0.08 & 0.071 & 22 & 19 & 20 & 3 & A & 23 \\
\hline Accounting and Business Research & 0.16 & 0.071 & 19 & 10 & 13 & 3 & A & 15 \\
\hline Accounting and Finance & 0.04 & 0.071 & 23 & 23 & 24 & & $\mathrm{~B}$ & 27 \\
\hline Accounting Forum & 0.15 & 0.084 & 9 & 12 & & 2 & B & 36 \\
\hline Accounting Horizons & 0.12 & 0.071 & 20 & 17 & 7 & 3 & A & 13 \\
\hline Accounting Review & 0.45 & 0.117 & 3 & 4 & 3 & 4 & $A^{*}$ & 3 \\
\hline Accounting, Auditing and Accountability Journal & 0.29 & 0.09 & 5 & 6 & 10 & 3 & $A^{*}$ & 8 \\
\hline Accounting, Organizations and Society & 0.45 & 0.09 & 6 & 2 & 4 & 4 & $A^{*}$ & 4 \\
\hline Auditing & 0.16 & 0.072 & 17 & 9 & 12 & 2 & A & 26 \\
\hline British Accounting Review & 0.133 & 0.08 & 13 & 14 & 18 & 3 & A & 18 \\
\hline Contemporary Accounting Research & 0.23 & 0.071 & 18 & 8 & 5 & 3 & $A^{*}$ & 7 \\
\hline Critical Perspectives on Accounting & 0.08 & 0.08 & 11 & 20 & 16 & 3 & A & 17 \\
\hline European Accounting Review & 0.1 & 0.071 & 21 & 18 & 18 & 3 & A & 10 \\
\hline International Journal of Accounting & 0.14 & 0.077 & 15 & 13 & 21 & 3 & B & 16 \\
\hline International Journal of Accounting Information Systems & 0.35 & 0.09 & 7 & 5 & & 1 & $\mathrm{~B}$ & 29 \\
\hline International Journal of Accounting, Auditing and Performance Evaluation & 0.04 & 0.071 & 24 & 24 & & 1 & $\mathrm{~B}$ & \\
\hline Journal of Accounting and Economics & 0.79 & 0.144 & 1 & 1 & 1 & 4 & $A^{*}$ & 2 \\
\hline Journal of Accounting and Public Policy & 0.12 & 0.08 & 14 & 16 & 14 & & A & 12 \\
\hline Journal of Accounting Research & 0.49 & 0.121 & 2 & 3 & 2 & 4 & $A^{*}$ & 1 \\
\hline Journal of Accounting, Auditing and Finance & 0.06 & 0.081 & 12 & 22 & 16 & 3 & A & 20 \\
\hline Journal of Business Finance and Accounting & 0.15 & 0.088 & 8 & 11 & 9 & & A & 5 \\
\hline Management Accounting Research & 0.12 & 0.084 & 10 & 15 & 8 & 3 & A & 14 \\
\hline Managerial Auditing Journal & 0.07 & 0.077 & 16 & 21 & 29 & 1 & $\mathrm{~B}$ & 31 \\
\hline Review of Accounting Studies & 0.27 & 0.099 & 4 & 7 & & 4 & A & 9 \\
\hline
\end{tabular}


Source: Adapted with permission from Emerald Journals and Moosa (2011, pp. 828-32) The details of how the different ranking systems works is beyond the scope of our paper.

- For Scopus see: http://www.scopus.com/home.url;

- For ABS rankings see http://www.associationofbusinessschools.org/node/1000257;

- for ERA (2010) see http://www.arc.gov.au/era/era 2010/era 2010.htm;

- and for $g$ and $h$-index see Moosa (2011, pp. 815-7). 
Table 2: Our analytical framework

\begin{tabular}{|c|c|}
\hline Attribute & Description and /or Options \\
\hline Journal & $A A A J, A O S$ or $C P A$ \\
\hline Page numbers & Actual page numbers of the article in the journal \\
\hline Authors & Names and count of authors \\
\hline Article name & Title as published \\
\hline Article type & $\begin{array}{l}\text { Research article; Viewpoint; Technical article; Conceptual article; } \\
\text { Case study; Literature review; General review }\end{array}$ \\
\hline Article orientation & Qualitative (0) Quantitative (1) \\
\hline $\begin{array}{l}\text { Sections } \\
\text { - } \text { Abstract } \\
\text { - Introduction } \\
\text { - Lit Review / hypothesis } \\
\text { - } \text { Context } \\
\text { - } \text { Theory } \\
\text { - } \text { Method } \\
\text { - Results } \\
\text { - Analysis } \\
\text { - } \text { Discussion } \\
\text { - } \text { Conclusion } \\
\text { - Notes } \\
\text { - } \text { Appendix }\end{array}$ & $\begin{array}{l}\text { For each section the following attributes were collected, Word } \\
\text { count (WC), position in article (P) and actual name of the } \\
\text { section. }\end{array}$ \\
\hline Total word count (TWC) & Excludes references at the end of each article \\
\hline $\begin{array}{l}\text { References, journal self } \\
\text { references, tables, equations, } \\
\text { plates and figures }\end{array}$ & Count of each from the article \\
\hline Perspective & First or third person \\
\hline Road map paragraph & Yes / No \\
\hline $\begin{array}{l}\text { The Writer's Diet } \\
\text { - } \quad \text { Be verbs } \\
\text { - } \quad \text { Abstract Nouns } \\
\text { - } \quad \text { Prepositions } \\
\text { - } \quad \text { Adjectives and adverbs } \\
\text { - } \quad \text { It, this, that, there } \\
\text { - } \quad \text { Total Writer's Diet score }\end{array}$ & $\begin{array}{l}\text { Use of the Writer's Diet website to assess quality of written } \\
\text { material based on the Introduction section of the article. Articles } \\
\text { were scored with Heart attack (4), Flabby (3), Needs toning (2), } \\
\text { Fit and trim (1) and Lean (0) }\end{array}$ \\
\hline
\end{tabular}




\begin{tabular}{|c|c|c|c|c|c|c|}
\hline AAAJ & \multicolumn{2}{|c|}{ Total } & \multicolumn{2}{|c|}{1 Author } & \multicolumn{2}{|c|}{$>1$ Author } \\
\hline Total number of articles & 39 & $100 \%$ & 10 & $26 \%$ & 29 & $74 \%$ \\
\hline Not published in $A A A J$ before & 16 & $41 \%$ & 5 & $31 \%$ & 11 & $69 \%$ \\
\hline Published in $A A A J$ before & 23 & $59 \%$ & 5 & $22 \%$ & 18 & $78 \%$ \\
\hline Unique $A A A J$ authors & 76 & $100 \%$ & 8 & $11 \%$ & 68 & $89 \%$ \\
\hline Not published in $A A A J$ before & 56 & $74 \%$ & 5 & $9 \%$ & 51 & $91 \%$ \\
\hline Published in $A A A J$ before & 20 & $26 \%$ & 3 & $15 \%$ & 17 & $85 \%$ \\
\hline AOS & \multicolumn{2}{|c|}{ Total } & \multicolumn{2}{|c|}{1 Author } & \multicolumn{2}{|c|}{$>1$ Author } \\
\hline Total number of articles & 43 & $100 \%$ & 14 & $33 \%$ & 29 & $67 \%$ \\
\hline Not published in AOS before & 10 & $23 \%$ & 6 & $60 \%$ & 4 & $40 \%$ \\
\hline Published in AOS before & 33 & $77 \%$ & 8 & $24 \%$ & 25 & $76 \%$ \\
\hline Unique $A O S$ authors & 81 & $100 \%$ & 12 & $15 \%$ & 69 & $85 \%$ \\
\hline Not published in AOS before & 43 & $53 \%$ & 6 & $14 \%$ & 37 & $86 \%$ \\
\hline Published in AOS before & 38 & $47 \%$ & 6 & $16 \%$ & 32 & $84 \%$ \\
\hline CPA & \multicolumn{2}{|c|}{ Total } & \multicolumn{2}{|c|}{1 Author } & \multicolumn{2}{|c|}{$>1$ Author } \\
\hline Total number of articles & 54 & $100 \%$ & 20 & $37 \%$ & 34 & $63 \%$ \\
\hline Not published in CPA before & 18 & $33 \%$ & 11 & $20 \%$ & 7 & $13 \%$ \\
\hline Published in CPA before & 36 & $67 \%$ & 9 & $17 \%$ & 27 & $50 \%$ \\
\hline Unique $C P A$ authors & 101 & $100 \%$ & 18 & $15 \%$ & 83 & $85 \%$ \\
\hline Not published in CPA before & 54 & $53 \%$ & 10 & $14 \%$ & 44 & $86 \%$ \\
\hline Published in CPA before & 50 & $47 \%$ & 8 & $16 \%$ & 42 & $84 \%$ \\
\hline
\end{tabular}


Table 4: General Framework for an Accounting Research Article

\begin{tabular}{|l|l|}
\hline Major section & Individual section \\
\hline Introduction & Abstract \\
\cline { 2 - 2 } & Introduction \\
\cline { 2 - 2 } & Lit Review / hypothesis \\
\cline { 2 - 2 } & Context \\
\hline Methodology & Theory \\
\cline { 2 - 2 } & Method \\
\hline \multirow{4}{*}{ The Back End } & Results \\
\cline { 2 - 2 } & Analysis and/or Discussion \\
\cline { 2 - 2 } & Conclusion \\
\hline \multirow{2}{*}{$\begin{array}{l}\text { Supporting } \\
\text { evidence }\end{array}$} & Notes \\
\cline { 2 - 2 } & Appendix \\
\cline { 2 - 2 } & Acknowledgements \\
\hline References & References \\
\hline
\end{tabular}

Source: Based originally on Guthrie et al. (2004 p. 417) and refined using our observations from our data set. 
Table 5: Mean, median and standard deviation of word counts in AAAJ, AOS and CPA articles (2010)

\begin{tabular}{|l|c|c|c|}
\hline & Mean & Median & Std. Dev. \\
\hline All Papers & 11,366 & 10,905 & 3,938 \\
\hline AAAJ & 10,485 & 10,650 & 3,378 \\
\hline AOS & 14,363 & 14,034 & 4,161 \\
\hline CPA & 9,617 & 9,660 & 2,574 \\
\hline
\end{tabular}

Table 6: Author self-citations in $A A A J, A O S$ and CPA (2010) articles

\begin{tabular}{|l|c|c|l|l|l|l|c|}
\hline & $\begin{array}{l}\text { Total } \\
\text { Articles }\end{array}$ & $\begin{array}{l}\text { Total } \\
\text { Citations }\end{array}$ & $\begin{array}{l}\text { Author } \\
\text { Self-citations }\end{array}$ & $\begin{array}{l}\text { \% Author } \\
\text { Self-citations }\end{array}$ & $\begin{array}{l}\text { Per } \\
\text { article }\end{array}$ & $\begin{array}{l}\text { Total } \\
\text { Incidences }\end{array}$ & $\begin{array}{l}\text { Average } \\
\text { Incidences }\end{array}$ \\
\hline AAAJ & 39 & 2637 & 158 & $6.0 \%$ & 4.1 & 276 & 7.1 \\
\hline AOS & 43 & 3833 & 141 & $3.7 \%$ & 3.3 & 313 & 7.3 \\
\hline CPA & 54 & 3465 & 168 & $4.8 \%$ & 3.1 & 319 & 5.9 \\
\hline
\end{tabular}

Table 7: Summary of average citations in AAAJ. AOS and CPA (2010) articles

\begin{tabular}{|l|c|c|c|}
\hline & $\begin{array}{l}\text { Total } \\
\text { Citations }\end{array}$ & $\begin{array}{l}\text { Journal } \\
\text { Self- } \\
\text { citations }\end{array}$ & $\begin{array}{l}\text { Author } \\
\text { Self- } \\
\text { citations }\end{array}$ \\
\hline AAAJ & 67.6 & 4.3 & 4.1 \\
\hline AOS & 89.1 & 11.8 & 3.2 \\
\hline CPA & 64.2 & 4.2 & 3.1 \\
\hline
\end{tabular}


Figure 1: Mean "Wasteline Test" results of AAAJ, AOS and CPA (2010) articles

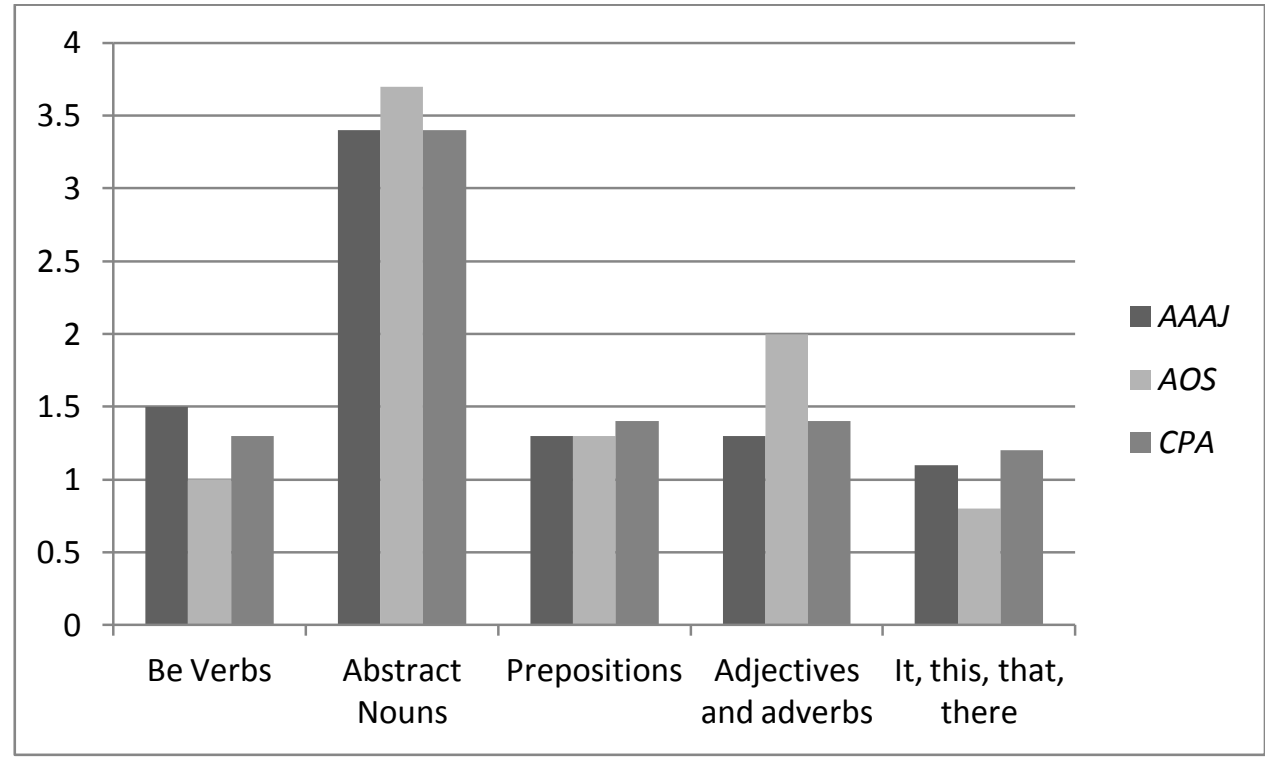

Figure 2: Number of References in $A A A J, A O S$ and CPA (2010) articles

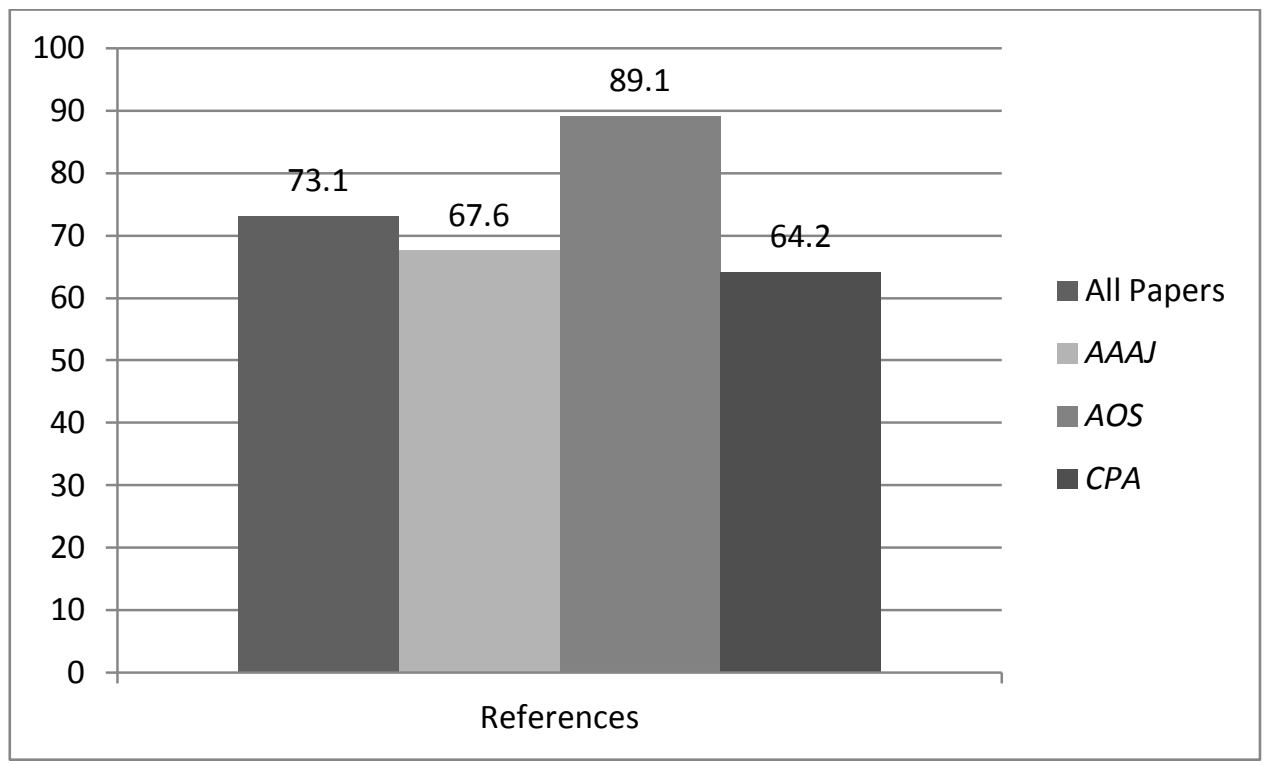


Figure 3: Percentage of journal self-citations in AAA, AOS and CPA (2010) articles

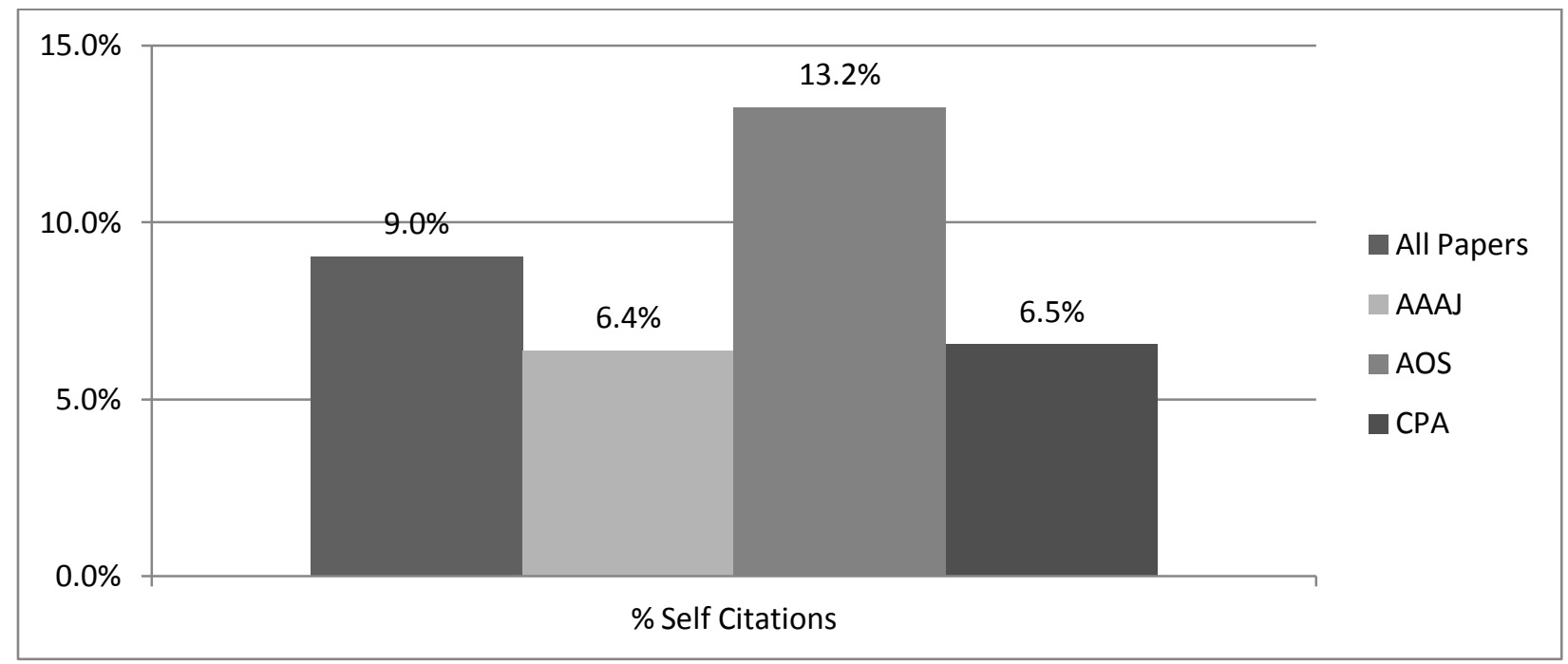

\section{Endnotes}

1 For example the University of Sydney Business School has a system whereby academics are rewarded with additional research funds dependent on the number and ranking of their research publications according to the Business School's ranking system, which is then given a point score. Academics receive between $\$ 500$ and $\$ 6500$ for each sole authored publication based on a $\$ 1000$ reward for each point for eligible journal articles. These research funds can be used by academics to fund further research work and/or to attend local and international conferences to present their current research findings.

${ }^{2}$ For example at the University of Sydney the 2011 Academic Promotions Policy states that, for the position of a full Professor, the candidate "Will have publications in peer reviewed international journals or creative works recognised under the ERA in [their] discipline and/or more broadly" University of Sydney. (2011), "Academic Promotions Policy", Retrieved 16 May 2011, http://sydney.edu.au/provost/docs/2011_policy/Promotions_policy_2011.pdf. This is not only the case in Australia but also in many other countries. For example, at the University of Alberta in Canada, accounting academics rely on regular publications in high ranking academic accounting journals for "annual wage increases, promotions and tenure decisions" Bédard, J. and Gendron, Y. (2003), "Qualitative Research on Accounting: Some Thoughts on What Occurs Behind the Scene", in C. Humphrey and B. H. K. Lee (Eds), The Real Life Guide to Accounting Research: A Behind-the-Scenes View of Using Qualitative Research Methods, Elsevier, Amsterdam, pp. 192-206.

${ }^{3}$ http://www.emeraldinsight.com/products/journals/journals.htm?id=aaaj accessed 27 August 2012. http://www.elsevier.com/wps/find/journaldescription.cws home/486/description accessed 25 June 2011. http://www.journals.elsevier.com/critical-perspectives-on-accounting/ accessed 27 August 2012.

4 http://www.elsevier.com/wps/find/journaldescription.cws home/622813/authorinstructions accessed 25 June, 2011.

${ }^{5}$ In this case the paper had already been approved by the reviewers and the editor only required some small changes before accepting the paper. However, the final email from the editor to the author stated "Papers published in [journal name] are in the formal, third person. In the revised paper you used 'our' a couple of times. Please change any references to 'our' or 'we' to 'the authors'. 
${ }^{6}$ See http://www.writersdiet.ac.nz/wasteline.html and the book Sword, H. (2007), The Writer's Diet, Pearson Education New Zealand, Rosedale, NZ.

${ }^{7}$ See http://www.emeraldinsight.com/products/journals/author guidelines.htm, accessed July 22011.

${ }^{8}$ A PDF copy can be downloaded from http://www.elsevier.com/wps/find/journaldescription.cws home/486/description

${ }^{9}$ See abstract guidelines at http://www.emeraldinsight.com/authors/guides/write/abstracts.htm

${ }^{10}$ However, authors may be discouraged by publishers from using visual elements because of problems associated with reproducing artwork, attaining artwork of sufficient quality to reproduce, and of course the omnipresent issue of copyright and permission to reproduce artwork.

${ }^{11}$ When the article had two or more authors and they were both authors of a referenced publication this is only counted as a single self-reference.

${ }^{12}$ We use the term "publications" because the self-citations refer to all manner of academic output including journal articles, conference papers, books, book chapters etc... 